\title{
Landscape, seascape and the ontology of places on Rossel Island, Papua New Guinea
}

\author{
Stephen C. Levinson \\ Max Planck Institute for Psycholinguistics, Wundtlaan 1, 6525 Nijmegen, Netherlands
}

\begin{abstract}
This paper describes the descriptive landscape and seascape terminology of an isolate language, Yélî Dnye, spoken on a remote island off Papua New Guinea. The terminology reveals an ontology of landscape terms fundamentally mismatching that in European languages, and in current GIS applications. These landscape terms, and a rich set of seascape terms, provide the ontological basis for toponyms across subdomains. Considering what motivates landscape categorization, three factors are considered: perceptual salience, human affordance and use, and cultural ideas. The data show that cultural ideas and practices are the major categorizing force: they directly impact the ecology with environmental artifacts, construct religious ideas which play a major role in the use of the environment and its naming, and provide abstract cultural templates which organize large portions of vocabulary across subdomains.

(C) 2007 Elsevier Ltd. All rights reserved.
\end{abstract}

Keywords: Landscape; Universals; Lexicon; Ethnogeography; Papua New Guinea; Oceania

\section{Introduction}

\subsection{Landscape as a conceptually interesting domain}

Onomastics and the study of toponyms (place names) ${ }^{1}$ has been for centuries one of the driest specialisms of linguistics. Two moves have recently been made that promise to bring

\footnotetext{
E-mail address: Stephen.Levinson@mpi.nl

1 'Toponym' is used here interchangeably with 'place name', as used elsewhere in this special issue.
} 
the study of toponyms into a more central place in the study of language and cognition. The first, initiated by anthropological linguists like Hunn (1996), Kari (1989) and others, has tried to relate the structure and type of naming to the use of landscape, and thus to develop a theory of place naming. The second, initiated by philosopher and cognitive geographer Smith and Mark $(2001,2003)$, has sought to relate place naming to folk theories of landscape features or landforms, and thus to develop a naive ontology of landscape, with a proper place amongst the basic human conceptual domains.

These developments revitalize the issues. Now we can ask interesting questions about the underlying conceptualizing of landscape, linguistic terms that describe them, and how these may relate to the naming of its parts. Landscape proves an interesting domain. First, from a geological point of view it is mere deformation of a continuous surface, so that discrete units and categories must be the construction of the cognizer. So landscape categories have little in common with ethnobiological categories which are driven by 'natural kinds', discrete types with their own behavioural and phenotypic repertoire, which exist independently of the cognizer. In that regard landform concepts are much more akin to the segmentations of the human body (see Majid et al., 2006), than to, say, the categories of ethnobotany (e.g. Berlin, 1992). Body parts might seem naturally partonymic, but in fact recent work on the nature of body parts suggests that they are only partially conceived meronymically, and that will prove almost certainly true for landscape terms. Like the body, landscape is a domain that all humans experience (even if they experience very different terrains), and comparative work across languages and cultures could be most informative. But while the segmentation of the body may be partly driven by the cognitive wiring that drives it, landscape features are more likely to be driven by their 'affordances', by what they are good for in human activities and purposes.

In this paper, I will argue that, contrary to Smith and Mark (2001), there is no universal folk ontology of landforms. For example, the concept of 'river', which they found to be one of the two or three most salient geographic features in Western populations, does not exist on Rossel Island (whose language and culture is described here) - or at least, not in the way that it does for English speakers. I will argue that culture, in the form of indigenous belief and mode of exploitation, plays a crucial role in constructing landscape concepts. These landscape concepts or categories, the outcome of cultural beliefs and activities, in turn form the ontological basis for the use of proper names, i.e. for toponyms. This precise mapping between the two domains - landforms and named places - though common is not inevitable, as shown by the Jahai example (Burenhult, this issue).

The theory (cf. Mark and Turk's, 2003a 'ethnophysiography') that would then emerge would hold that there are many degrees of freedom between, on the one hand, the continuous geological surface, and on the other, culturally recognized landform features and principles of toponymy. For example, cultural beliefs and practices may play an important role in recognizing and indeed creating landforms by human activity. In addition, the relation between landform concepts and toponyms can be variable. How then could we account for any universal tendencies to distinguish and name mountains, rivers, lakes and the like? Overall three distinct theories of category formation in this domain spring to mind:

1. Categories are driven by perceptual or cognitive salience. This suggests there should be significant universals in categories like mountain, river, lake, cliff. 
2. Categories are driven by the affordances they offer or the constraints they impose on human activities. This suggests that there should be systematic variation according to subsistence patterns, ecology and the technology of transport.

3. Categories are driven by conceptual templates and cultural beliefs. This suggests greater variation, with universals if any driven e.g. by universals of cognition, cosmology or religious belief.

The Rossel data will suggest that, although all three motivations seem to be at work, it is the last two that are probably dominant in local human categorizations of the environment.

The focus of this paper then is on the indigenous categories of landscape and seascape features, as shown both by the types coded in common nouns, and individual representatives of those types coded in toponyms or proper names. The underlying questions are: Are there underlying conceptions that can be seen to drive the category system? What precisely demarcates a particular category? What drives recognition of this category (e.g. salience, utility, cultural belief)? When individual tokens of these types are named, what singles them out for proper names?

\subsection{Rossel Island}

This paper outlines the linguistic descriptors used for landform and place designation in Yélî Dnye, the language of Rossel Island - this is a so-called 'Papuan' (i.e. non-Austronesian) language isolate spoken on the easternmost landfall of the Louisiade Archipelago in Papua New Guinea (154.14E, 11.22S). ${ }^{2}$ Recent research suggests linguistic continuity for over 10,000 years (Dunn et al., 2005), and the language is the first language of the whole population, which is ethnically and genetically distinct from neighbouring peoples. Colonization was gradual, beginning in 1885 with a British Protectorate for the archipelago, a plantation run by a single white family from 1903, and missionization culminating in the establishment of an effective Catholic mission in 1953. Despite this colonial contact up to independence in 1975, the major remaining traces are mission buildings and schools, and widespread small coconut plantations - there are no roads or bridges or general power or water supply on the island. Due to its remote location among difficult reefs 260 nautical miles offshore from the mainland, modernization has largely passed Rossel Island by (Fig. 1).

The island is a landmass of preMiocene metamorphic geology, $34 \mathrm{~km}$ by $14 \mathrm{~km}(265$ square $\mathrm{km}$ ), with a rainforest-clad central mountain range over $850 \mathrm{~m}$ high, set within a huge barrier reef. The population stands at something over 4000, and exploits the inland forest for nuts and game, planting taro deep in the mountains and coconuts and other roots crops nearer the coast in a simple slash-and-burn agricultural system without irrigation. Most protein comes from the sea, which is intensively exploited (Fig. 2).

\footnotetext{
${ }^{2}$ This paper supersedes Levinson (2002), which was based on preliminary explorations of this linguistic domain.
} 


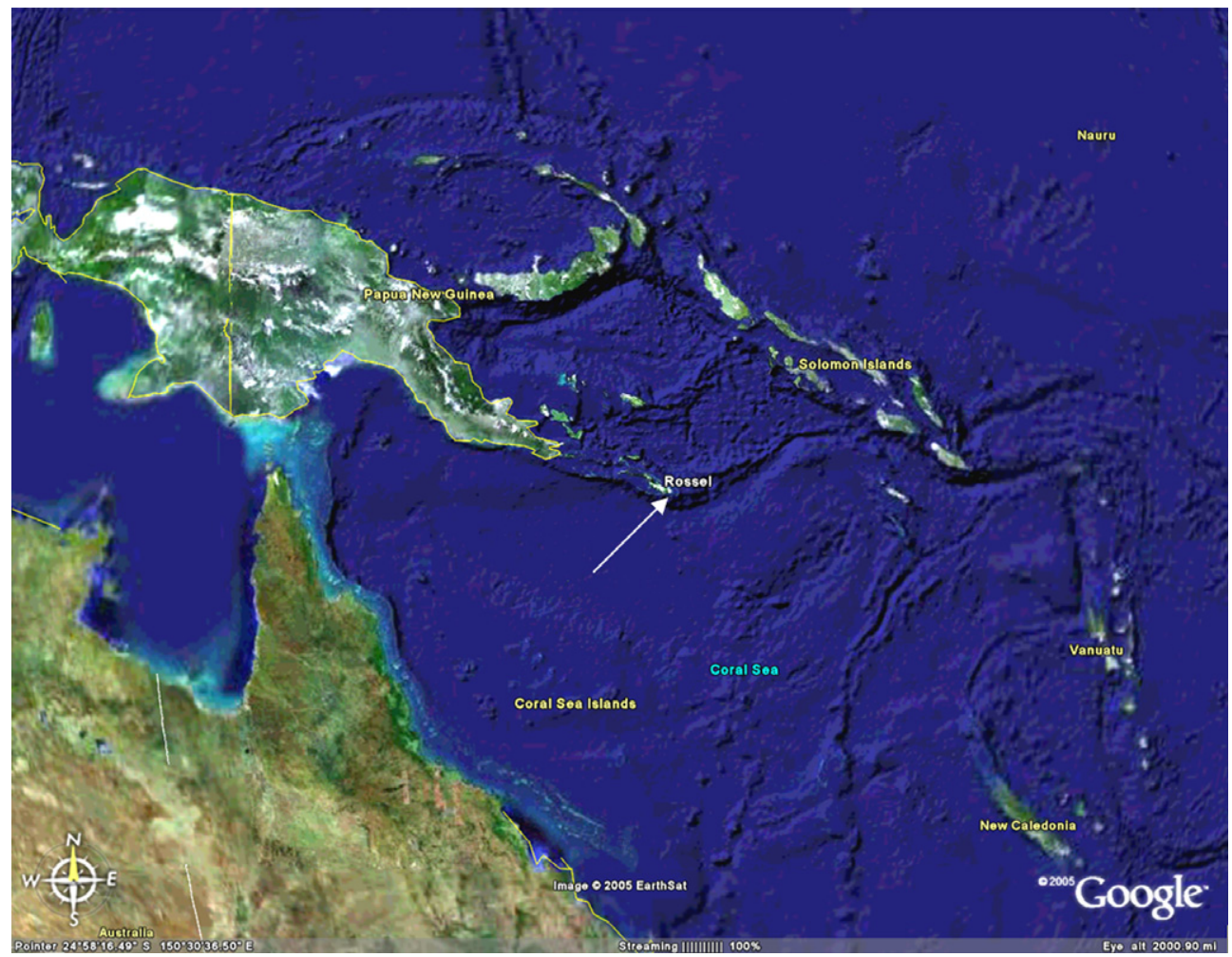

Fig. 1. Location of Rossel Island.

A small island, probably inhabited continuously by the same people since the Pleistocene, is an interesting natural experiment: What sorts of landforms does this indigenous cultural tradition recognize? Amongst the surprises is that seascape is almost as important as landscape, and that cultural factors seem dominant almost everywhere. Here is a catalogue of some of the surprising features:

1. Scale plays only a minor role in distinguishing landforms, and motivating toponyms. Single rocks may have proper names, as may small portions of reef, or pools in the lagoon.

2. An underlying 'force dynamic' template seems to be at work, distinguishing between 'up', 'down' and 'over' places, directions and actions. This plays an important role in segmenting e.g. water courses, lagoon areas, elevations, and paths, and is reflected linguistically in many toponyms.

3. Notions like 'mountain', 'river', 'cliff', 'valley', etc., which have been thought to be good candidates for universal concepts (Smith and Mark, 2001), do not have direct counterparts.

4. An historically small population (1500 till 50 years ago) on a large island difficult to traverse nevertheless had an extremely dense system of toponyms over both land and sea. 


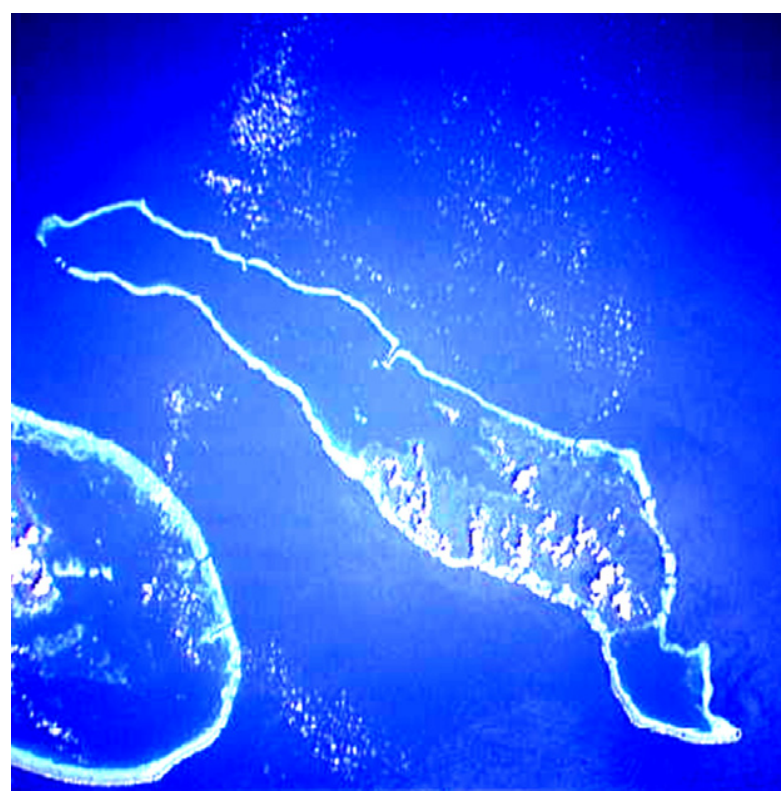

Fig. 2. Rossel Island from space. The Rossel reefs are the diagonal structure, ca. $100 \mathrm{~km}$ long, with clouds over the island itself. The Sudest barrier reef is visible to the lower left.

In what follows, I will examine both generic landscape terms - categories for landforms and indeed seascape - and the corresponding toponyms, which in this language seem closely correlated.

\subsection{Structure of the paper}

The rest of this paper is organized as follows. First, in Section 2 it is shown that a handful of the Rossel landscape terms suffice to demonstrate that there is no universal ontology of landscape entities, as has been proposed. Section 3 then reviews some of the major landscape subdomains in turn: elevations (nearest equivalents to hills, mountains, ridges and the like), the botanical cladding (nearest equivalent to forests and the like), watercourses (the nearest equivalents of rivers, streams, springs and the like), and finally seascape, which is of enormous importance to the inhabitants. In reviewing each of these subdomains, it is shown that there is a precise parallel between the ontology established by generic landscape terms and the toponyms that pick out instances of them. Section 4 reviews the impact of culture on landscape notions, covering three rather different factors: the human imposition of categories and constructed objects in the landscape, the consequences of a religious system that views gods as immanent in the landscape, and finally, the role that a cognitive model or cultural template plays in giving an underlying abstract structure to this domain. I argue that a single conceptual template, with slight adaptations to subdomains, accounts for many features of the Rossel landscape terminology and toponyms - a template revealed most clearly in verbs of motion. The conclusions in 5 make the point, inter alia, that perceptual criteria play only a small role in the Rossel landscape 
terminology, while cultural factors are predominant motivations for the recognition of specific categories.

\section{Rossel and putative universals: mountain, river, sea}

With the rapid growth of geographic information science, the technologies of GIS (geographic information systems) and GPS (global positioning systems), the ontology of landscape forms has become of tremendous practical importance. GoogleEarth, or the humble car navigation device, presume a universal ontology of landscape objects (rivers, mountains, roads, buildings and the like) onto which proper names, for example, can be mapped. Geographers have therefore been interested in whether this presumption is justified. Smith and Mark (2001) tested this by asking subjects to list the first geographical features that came into their heads. The most frequent responses were, in order: Mountain, River, Lake, Ocean, Valley, Hill, Plain, which they took to indicate protypical members of the category. Because they were able to reproduce this in Finland, Croatia and the UK, they suggest that "there is just one (folk) ontology of the geospatial realm" (p. 610), which belongs to Horton's (1982) 'primary theory' which "is that part of common sense which we find in all cultures and in all human beings" (p. 597; see also Smith and Mark, 2003). (To be fair to Mark, he has since abandoned this position (see Mark and Turk, 2003a,b), but since so many practical GIS systems make use of a universal ontology, it is important to test its veracity.)

The Rossel Island 'emic' categories for landscape categories directly show these presumptions to be wrong. Take for example those ontological entities most prominent for Western subjects: Mountain, River, Ocean - nothing precisely like them exists in Rossel concept or language, even though they form important parts of their environment as English-speakers conceive it. ${ }^{3}$

Let us start with 'mountain'. The Yélî Dnye term $m b u$ certainly covers mountains. Perhaps the prototype $m b u$ is the highest mountain on the island, $M g \hat{\imath}$ by name, shown in Fig. 3. But unfortunately for the 'mountain' gloss for $m b u$, the same term applies to conical elevations of any size, even a heap made by a burrowing crab on the beach, as also shown in Fig. 3. However, the gloss 'conical elevation' suggests a three-dimensional cone, and that turns out to be too strict a condition. Consider Fig. 4, which shows the highest mountain range on Rossel, with named mountain peaks, or rather named $m b u$. Halfway down the flank is a rocky ledge called Wââdî, which is also an $m b u$. At first sight this is puzzling, as it does not look like a conical elevation - but from beneath, looking northeast, it does indeed appear like a cone, as shown in the inset. The correct gloss for $m b u$ is thus something like 'an elevation of any size, which has a conical projection from at least one viewpoint'. This landscape term thus seems to be a concept with a shape definition: since size is irrelevant, the concept is not driven by human affordance or activity (you can step over a crab heap but not over a mountain), and no special cultural constructs are involved.

\footnotetext{
3 Throughout this paper I make contrasts between the Rossel and (British) English landscape terms, presuming that my intuitive understandings of the English terms match those of the reader. This may be unwarranted, as it is entirely possible that there is dialectal variation or sheer indeterminacy. Less defensibly, here and there I slip into using English as a metalanguage, but the alternative would be to use geographical terminology which the majority of readers are unlikely to command.
} 


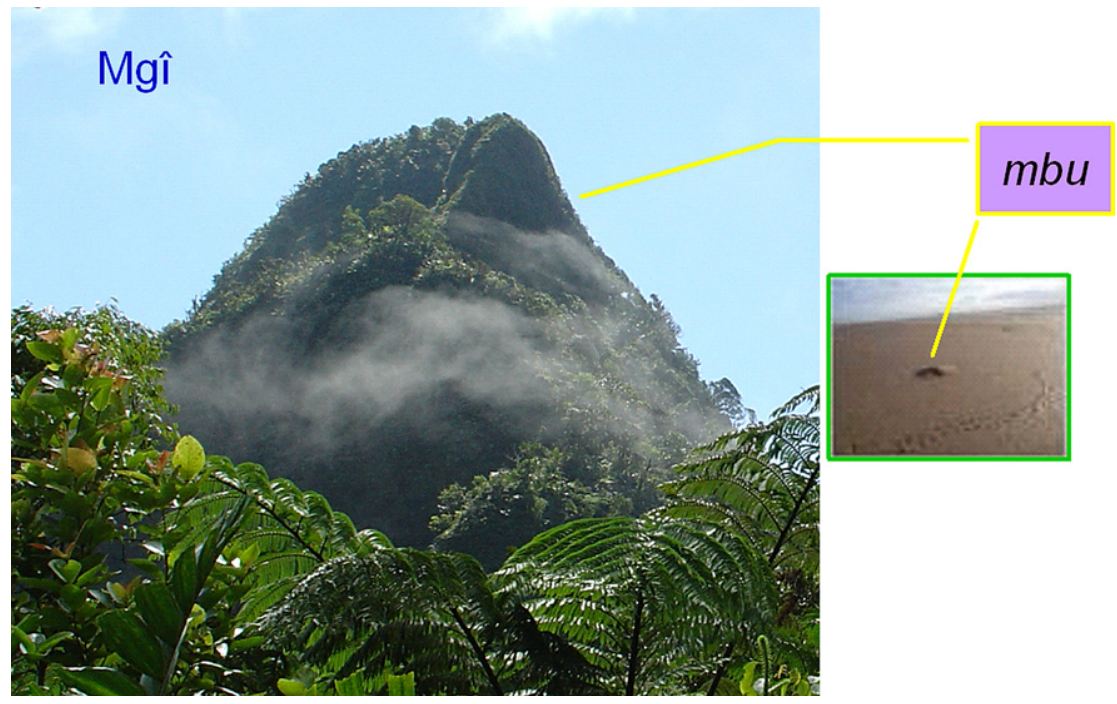

Fig. 3. Mbu as 'conical elevation of any size'.

Turning to the concept 'River', this is also a case where there is no match between English and Yélî Dnye. Yélî Dnye distinguishes three segments of a major watercourse, as shown in Fig. 5. The highest part, called mbwaa 'fresh water or fresh-watercourse' runs from source to the highest point of the tidal reach - the mbwaa is habitat for much prized water eels, prawns and fresh water fish. It is also used of course for drinking and washing (but not cooking, which is done with salt water usually collected form the lagoon). The next stretch is pye, the tidal or salt water reach, which can be a good part of the whole length of the watercourse. It is usually navigable for sailing canoes, sometimes even for large vessels. It is the habitat for (man-eating) crocodiles, and distinctive fish or fish in a particular life-cycle stage - a favourite community pastime is poisoning this stretch of the river to yield a large catch of fish. The final stretch of the watercourse or kpé is an unbounded flow between the shore and the reef opening (which the fresh water erodes and maintains). It is usually very deep, so crossing it by canoe requires paddling or sailing rather than punting, and it may harbour big fish and sharks. These three segments seem to be distinguished not so much by perceptual criteria (the kpé is only visible in heavy rains, when the muddy runoff makes this portion of the watercourse visibly distinct), but by human affordance and activity (distinct types of fishing, or transport). Interestingly, these three segments can be united by a single proper name (e.g. Pene mbwaa, Pene pye, Pene kpé), making the point crystal clear that neither the whole three segments nor the parts correspond to our notion of a river.

Finally, the concept 'Ocean' which was the fourth most salient geographic feature for American and European subjects in Smith and Mark's (2001) experiments, has no unitary corresponding term in Yélî Dnye. This is because the sea is of enormous importance to Rossel people, and they make many distinctions between kinds of sea, according to depth, kind of bottom, enclosure by reef, etc., as described below (Section 3.4). We can illustrate this by looking at the terminology just for the different areas of the lagoon waters and 


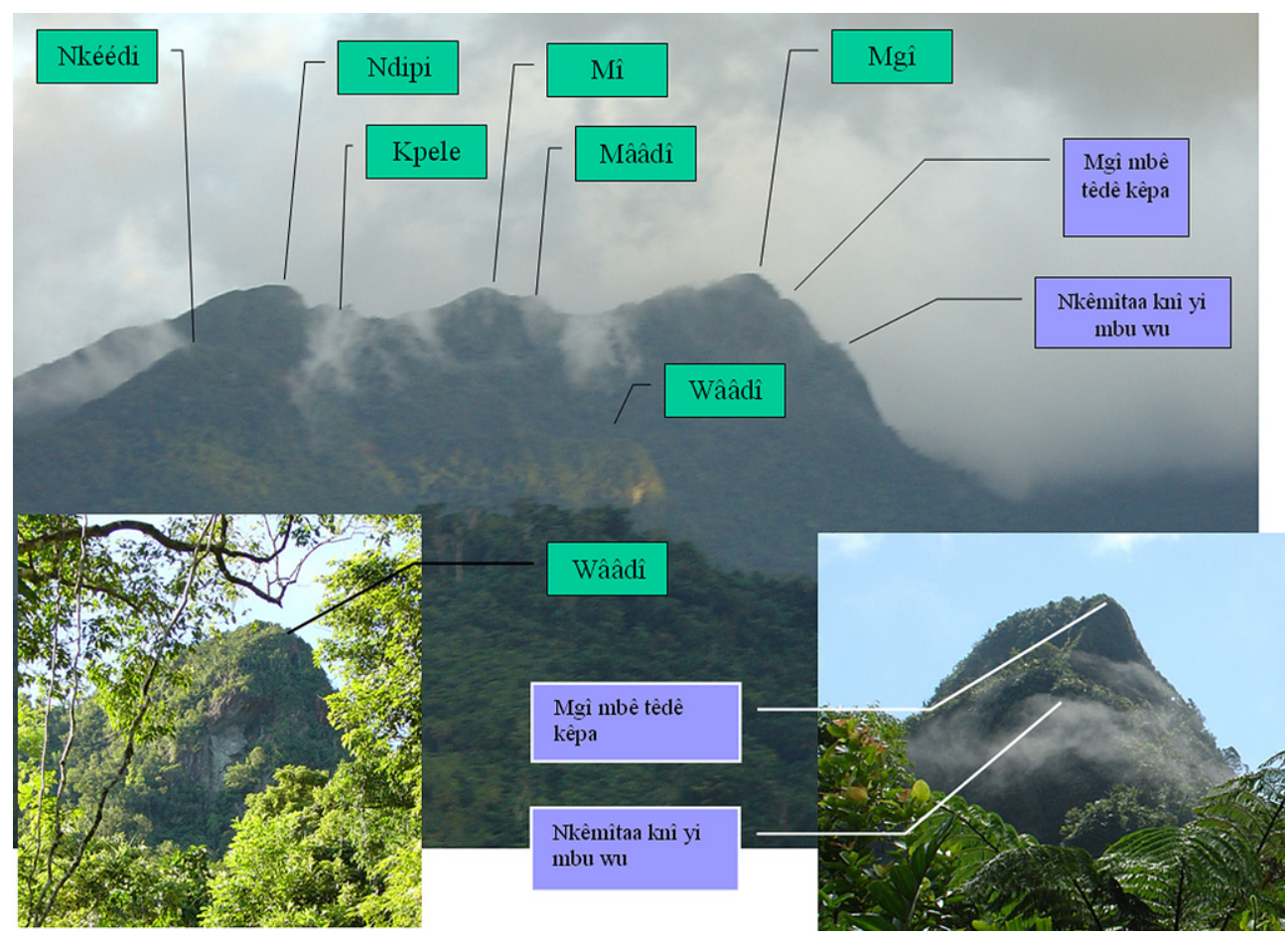

Fig. 4. Named peaks around Mgî (Mt Rossel), from the northwest. This figure shows how conical peaks, or $m b u$, (green labels) are the main named elevations. The apparent exceptions prove the rule: Wââdî appears like a sunlit rocky flank in the top photo, but indeed appears conical from below as shown in the left inset. In the right inset is Mgî from the south, with the name of the lower feature glossing 'mbu of the Nkêmitaa's' - as shown in the main photo to the right, this feature in profile is only a brow on the main peak. The pictures make the point that $m b u$ need only have a conical elevation from one viewpoint. The dark foreground hill in the main picture is also an $m b u$.

beyond, as given for Yélî Dnye in Fig. 6 Panel A. Panel B shows the comparable vocabulary in the Kilivila language of the Trobriand Islands (thanks to my colleagues Gunter Senft, for the data, and Niclas Burenhult, who made the comparison). Although the reef and lagoon physiography is very similar in the two areas, the systems clearly do not match (more will be said about the Rossel system below). Just as in the Trobriands (Senft, this issue) or on Anuta in the Solomons (Feinberg, 2005), the ocean is taxonomized, and there is no clear Yélî Dnye cover term, except perhaps ntii, 'salt water'.

These three examples show that geographic terms familiar from English will not necessarily translate, even roughly, to less familiar, especially non-European, languages. They thus demonstrate that there is no universal 'folk' ontology of the kind that global information systems normally presume, and one can predict that a fair bit of cross-cultural misunderstanding may be generated not only by e.g. GoogleEarth or the many GIS projects being conducted in developing countries by NGOs, but also by international treaties based on GIS, concerning e.g. the law of the sea, land ownership or international boundary disputes. Further detail about the particular Rossel concepts mentioned here will be given below. 


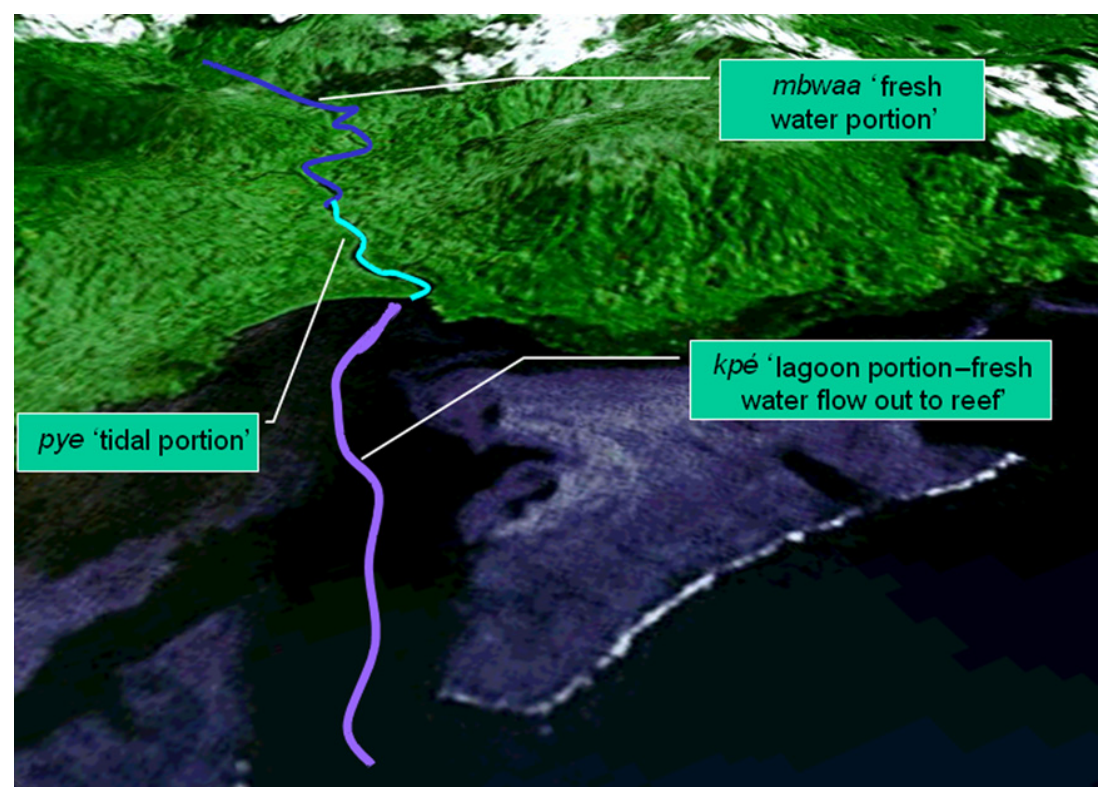

Fig. 5. Abeleti (Kêna) water course and reef structures, from south. Curiously, unlike its minor tributaries, this large navigable river has no proper name - it is designated by the area name, Kêna, thus Kêna pye, Kêne mbwaa, etc.
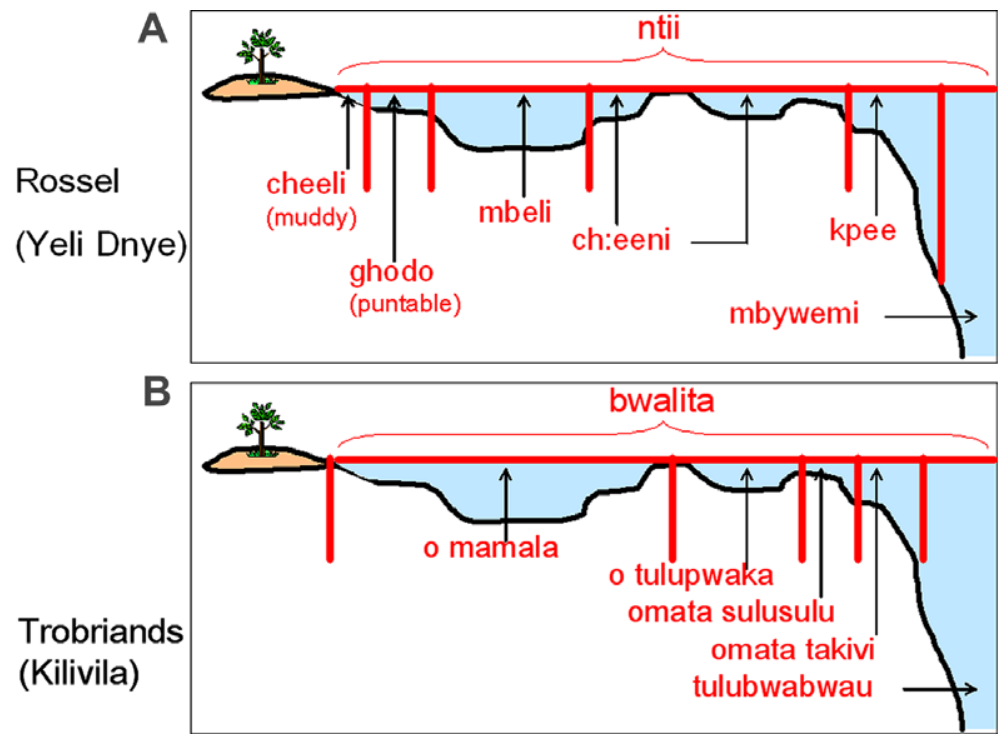

Fig. 6. Cross-section of lagoon, showing terms for distinct kinds of water area in two societies with similar maritime ecologies. 


\section{Landform/seaform terms and toponyms across some major ecological zones}

In this section, a number of major types of geographical zone are reviewed, and the landscape or seascape terminology is described. This kind of detail will be essential if we are, in the future, to have a proper cross-linguistic comparison of this domain. A major purpose here, however, is to show that the Yélî Dnye landscape/seascape terms provide the systematic basis for Yélî Dnye toponyms: that is, the land/seaform terms provide the ontology, in terms of common nouns or categories, for the place names, or proper nouns, which are directly referential, singling out specific places as the referred-to instances of the category. This we can show by demonstrating that for each of the landscape/seascape descriptive terms (bar a few exceptions), there is a good range of toponyms that name specific instances of the feature.

Could it be otherwise? Readers are referred to Burenhult (2005, this issue) who describes a system in Jahai where riverine landform terminology systematically mismatches with toponyms, with an efficient division of labour and no overlap between the two set of concepts (landform terms, vs. nameable entities). Notice that even in English there is a division between monomorphemic place names (London, The Thames, Snowdon, etc.) and binomials where the first part is a proper name or descriptive element and the second a landform feature (Windmill Hill, Seven Springs, Hampstead Heath, etc.) - we do not expect a spring, a small hill or a small heath to have a monomorphemic proper name of its own. On Rossel, though, small patches of land or reef or sea, even a rock, may have a monomorphemic proper name, denoting a token of the corresponding common noun types, i.e. land or seaform terms. Although Yélî Dnye toponyms are often multimorphemic, in many of these some of the individual morphemes are uninterpretable. In other cases, there may be a descriptive element that has, for the speakers, lost its literal meaning (cf. Tonbridge, Portsmouth). Finally, there are descriptive cases, like Cheme lyoko 'Cheme (village) canoe-dock'. The main difference with English, then, is that monomorphemic or opaque multimorphemic toponyms are not restricted to major geographical features or conurbations - the line between undescriptive and descriptive toponyms is drawn in a different place.

Incidentally, Rossel toponyms form a syntactically distinct word (or phrase) class, with special distributional properties, since they occur without locative postpositions, unmarked in locative as well as allative and ablative functions.

\subsection{Elevations}

Under the rubric of elevational terminology, I will collect terms that refer both to convex and concave landforms (i.e. to uplifts and depressions). On first principles, mountains, peaks, and hills are the kind of objects that, wherever they exist, might thrust themselves into human cognition on the basic principle of perceptual salience. Although initially it might seem that there are Yélî Dnye terms that gloss 'mountain', 'hill', 'valley' and the like, careful inspection shows that the terms actually have rather different extensions. We have already seen that although $m b u$ is a term that applies to mountain peaks, which invariably have proper names too, it is also a term that applies to small hills, and really seems to apply to any elevation that has a conical projection from at least one side.

The term kpâpu, which at first sight seems to gloss 'hill', cannot in fact exactly mean that since $m b u$ preempts it: most things we would call a hill, are said to be $m b u$. Kpâpu 
really seems to denote a range of hills, or a horizontal, rolling ridge. However, there is another term, dêpwo, for a ridge that leads up the flank of a mountain. In the same way, vyuwo, which at first seems a good candidate for 'valley', in fact just denotes the bottom of any inclined plane (which is a dêpwo or dêma). It thus describes the point where an elevation flattens out, and can therefore be applied to the lower flanks of a mountain. In fact, vyuwo belongs to a systematic opposition to be described below in Section 4.1 between UP, DOWN and OVER (it is not an accident that it also means 'wave', presumably referring to the troughs rather than the crests). The OVER part of this opposition corresponds to chóó, which denotes a col, mountain pass or saddle over a hill. These passes are where well worn paths pass through the thick rain forest (otherwise unpassable) and over the mountain ranges.

A further feature, t:aanî may seem to mean cliff, because a cliff can be so called, but in fact it just means 'rock, bedrock'-t:aanî pee 'rock piece' comes close to cliff, but is still a much more general term (another term pyoko has application to cliffs - it seems to mean something like 'stony place', but its exact sense is uncertain). Similarly, mwaa refers to stony ground, but its primary reference is to a boulder field, along with its distinctive vegetation. In fact, overall there seems to be no term for elevations or parts of them which closely matches English landscape terms. If we ask the question, raised in Section 1.1, namely what drives the classification of these features, the answer would seem to be that apart from $m b u$, with its perceptual definition, and apart from $t$ :aan $\hat{\imath}$ with its substance definition (rock), the rest of the terminology seems geared to human affordance - ridges being classified according to whether they lead up a mountain or not, and passes over mountains being picked out. As for negative elevations or depressions, although there is no term for valley, there is a term that apparently means 'gorge' (weelyunkoo), and a general term for lower slopes or lowlands (wee ghi, or paa ghi).

Turning to corresponding proper names, Fig. 7 shows some typical named elevations. Most of these are named peaks, or $m b u$, but there is also a named notch or pass, and in the foreground a named horizontal ridge or kpâpî. Fig. 8 shows some named mountain passes or chóó, which vary in profile from a visible notch to a saddle.

Table 1 below lists the elevation terminology, pairing landform terms (with English glosses indicating rough extensions) with proper names for specific instances. Note that apart from the more specific binomials, nearly all landform terms seem to have corresponding instances of proper names (dêpwo is not clearly distinct in meaning from dêma).

\subsection{The botanical cladding}

It is not at all clear that vegetation types belong to the landscape domain in Rossel native conception. In the Rossel origin myth, the creator god Ngwonoch:a found the island bare of vegetation - it was a mere rocky outcrop, and he duly clothed it in vegetation. The insight of course is that the geology and physiography is independent of the vegetation, and indeed drastic cyclones and the massive landslides which follow make that self-evident.

Rossel people are well aware that once tââ, virgin rain forest, is felled, it is irretrievably lost, at least for many generations. Large tracts were felled for plantations in the last century. There are specific tree species that occur only in tââ or in mbwóó, secondary regrowth after use for slash and burn agriculture. Forest types are therefore not static, nor do they 


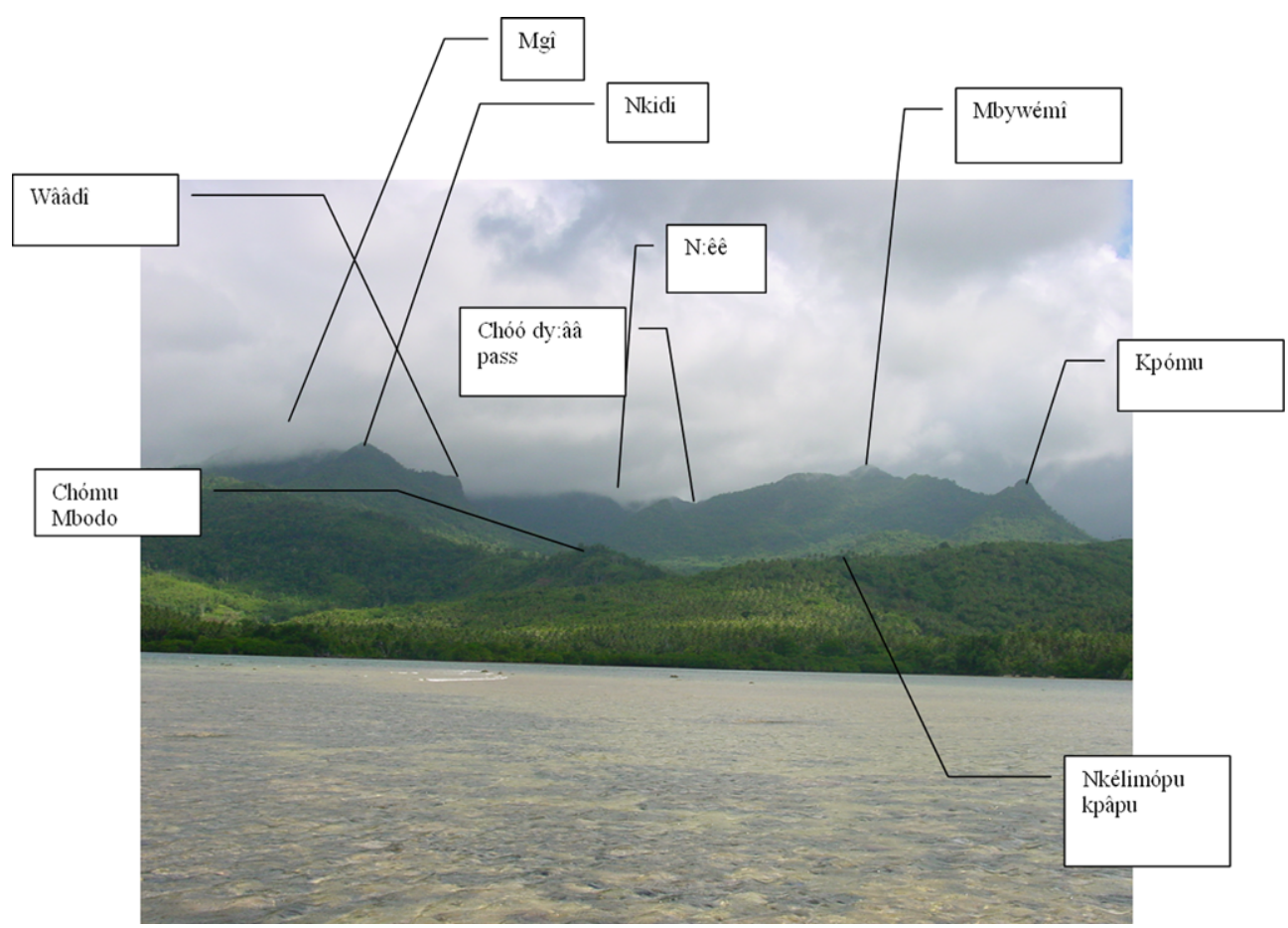

Fig. 7. Typical named elevations - looking southwest from the reef. $M g \hat{\imath}$, Mount Rossel $(850 \mathrm{~m}$ high) is hidden (as is typical) in the mist to the left, behind Nkidi. Wââtî is the mount with the steep cliff or t:anê pe, which presents a conical elevation from the west. From the water's edge, the first range, or dêma tii, is the Nkélimópu ridge (Nkélimópu kpâpu), also called a kpâpu tii, or hill range. The central hillock is called Chómu Mbodo, a small $m b u$. Wââu river can be seen entering the lagoon to left (this dip is not a vyuwo - which is the bottom of an incline, where the land flattens out). From right, the mountain is Kpómu, the next high peak is Mbywémî. The mountain in the middle is $N: \hat{e} e$ (partly hidden in mist), the path (Chóó dy:ââ) to Njââdî goes over the dip just to the right of it. In front of it, the whole central curve encloses the district of Vyele wee, where the sunlight is falling. Yamayu district lies seaward and to the right but extends into Nkélimópu ridge.

form delimited areas. On the whole, therefore, natural vegetation areas do not seem to have proper names (although there are area names where particular vegetation is predominant of course). Only grassy knolls, of coarse kunai grass (Imperata cylindrica), appear to have both a delimited area and a stable character - hence only they seem to have proper names. ${ }^{4}$ Areas used by humans, such as plantations, old and current garden sites, etc., do of course also have proper names.

There is a contrast often made between $n k o o$, deep rain forest, and pyi or coastal vegetation (largely secondary growth, plantation or coastal species), and a composite term pyi nkoo, for intermediate vegetation areas. Table 2 provides some salient vegetation terms. (More will be said of human effects on the environment in Section 4.) It should be noted that there are semi-productive ways to specify vegetation types by compound-

\footnotetext{
${ }^{4}$ How would we know if the proper name refers to the grassy patch or the underlying landform? Only by getting native exegesis - the reference of these place names is explained by referring to the vegetation.
} 


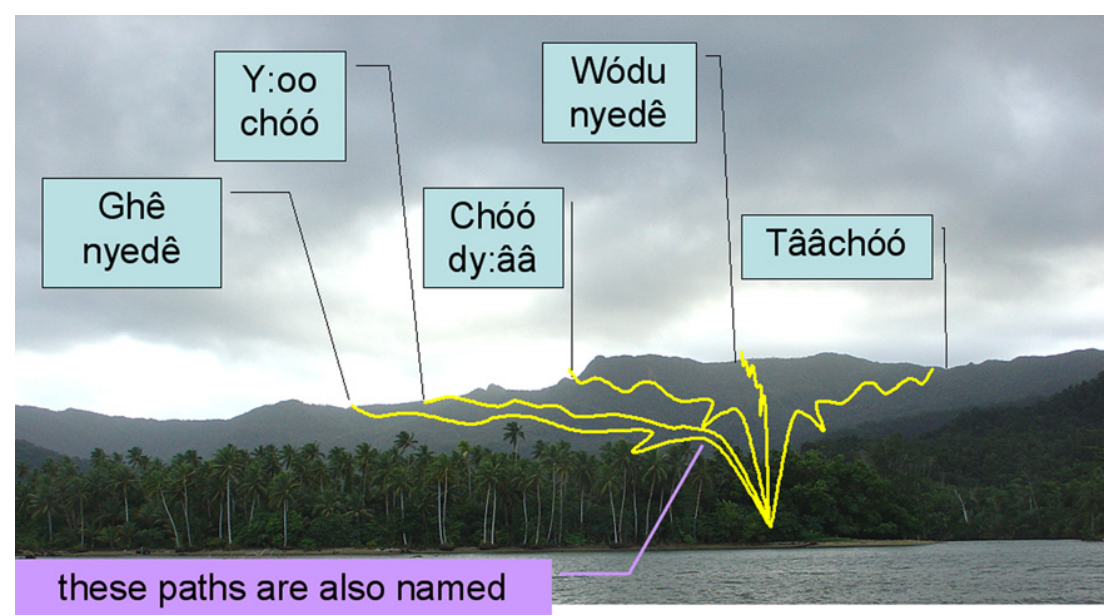

Fig. 8. Some named passes over the central mountain range, viewed from the south side of the island. These names often incorporate chó 'pass', or (place-name) nyedê 'near/on top of (place-name)'.

Table 1

Elevations: landform terms and corresponding proper names

\begin{tabular}{|c|c|c|c|c|}
\hline Elevations & Landform terms & Gloss & Proper names & Notes \\
\hline & $m b u$ & $\begin{array}{l}\text { Point, mountain, hill, conical } \\
\text { elevation }\end{array}$ & $Y: \hat{e} m \hat{\imath}$ & $\begin{array}{l}\text { The mountain of the } \\
\text { dead }\end{array}$ \\
\hline & mbu wêê & Small hill & Nt:aambene & Hill above Njinópu \\
\hline & kpâpu (tii) & Horizontal ridge, row of hills & $\begin{array}{l}\text { Nkélimópu } \\
\text { kpâpu }\end{array}$ & Village name + ridge \\
\hline & dêma & Ridge up an elevation & Maalum & Ridge to Tââchó \\
\hline & dêma tii & Long ridge & & \\
\hline & dêpwo & Incline, inclined ridge & & \\
\hline & vyuwo & $\begin{array}{l}\text { Bottom of elevated feature, where } \\
\text { land flattens out }\end{array}$ & Mgî vyuwo & Base of Mt Rossel \\
\hline & weelyunko & Gorge (?) & & \\
\hline & chóó & Mountain pass, saddle, col & $\begin{array}{l}\text { Tââchó, Wódu } \\
\text { nyede }\end{array}$ & Pass names \\
\hline & paa & Flank of mountain or hill & $\begin{array}{l}\text { Kpéé paa, } \\
\text { Wóó paa }\end{array}$ & $\begin{array}{l}\text { Village name, river } \\
\text { name }\end{array}$ \\
\hline & paa ghi & Area of steep incline, lower slopes & & \\
\hline & waa ghi & Lower slopes, lowlands & & \\
\hline & pyoko & Stony place (?) & & \\
\hline & t:aanî & Rock, cliff, scree & Yidika & $\begin{array}{l}\text { Particular rock on a reef } \\
\text { (see 4.0) }\end{array}$ \\
\hline
\end{tabular}

ing, e.g. kpéki-dodo, formed from the names of two shrubs, denotes the kind of vegetation found exclusively on boulder-fields (or mwaa). Omitted from this table are terms for mangrove areas, since these are dealt with in Section 3.4, but it should be noted here that the basic name for a mangrove belt and swamp is ghêed $\hat{\imath}$, which is also the name for just one of many species of local mangrove. 
Table 2

Terms for vegetation types

\begin{tabular}{|c|c|c|c|c|}
\hline $\begin{array}{l}\text { Natural } \\
\text { vegetation types }\end{array}$ & \multicolumn{2}{|l|}{$\begin{array}{l}\text { Generic } \\
\text { terms }\end{array}$} & \multicolumn{2}{|l|}{ Proper names } \\
\hline & chii & Bush, natural forest growth & & \\
\hline & nkoo & Deep rain forest & & \\
\hline & pyi & Coastal forest & & \\
\hline & pyi nkoo & Intermediate forest type & & \\
\hline & tââ & Virgin forest, and its soil & & \\
\hline & mbwóó & Old secondary regrowth, and its soil & & \\
\hline & w:ongo & $\begin{array}{l}\text { Old garden site, secondary forest } \\
\text { regrowth ca. } 10-20 \text { years old }\end{array}$ & Womu wee & $\begin{array}{l}\text { Mépé's old } \\
\text { garden }\end{array}$ \\
\hline & wuduma & Old garden site with charcoal in soil & & \\
\hline & kêêî d:ê & One's prior garden site, now regrowth & & \\
\hline & yâpwo têdê & Current garden site ${ }^{a}$ & Dmyiniyichó & $\begin{array}{l}\text { Raymond } \\
\text { Y:eemwe's } \\
\text { garden }\end{array}$ \\
\hline & $k n w i$ & $\begin{array}{l}\text { Special type of high montane, unburnt } \\
\text { garden }\end{array}$ & & \\
\hline & $k p \hat{e}$ & Plantation of palms or sago & & \\
\hline & wókó & Large sago plantation & Pwopu & $\begin{array}{l}\text { Planted by } \\
\text { 'Nów:a near } \\
\text { Cheme }\end{array}$ \\
\hline & wédi kpê & Small sago plantation & & \\
\hline & $k m: i i k p \hat{e}$ & Coconut plantation & Kanềnuwo & $\begin{array}{l}\text { Old Pambwa } \\
\text { plantation }\end{array}$ \\
\hline & $t: a a k p \hat{e}$ & Betelnut plantation & & \\
\hline & $w: a m \hat{\imath}$ & Grassy space with spiny komo grass & $\begin{array}{l}\text { Pulikpê } \\
\text { Wamî }\end{array}$ & $\begin{array}{l}\text { Where Nt:aatpi } \\
\text { lived }\end{array}$ \\
\hline
\end{tabular}

a Stages in garden making have their own terms: stage 1, with felled trees, is called a kp:aa, stage 2 when the logs are left to dry out is châa, stage 3 when the understory growth is cleared is ngméti, preparatory to firing, which results in stage 4, yâwpo têdê.

\subsection{Rivers and drainage}

As we saw in Section 2, there is no Rossel concept (at least as expressed in Yélî Dnye) that matches the notion 'river'. As shown in Fig. 5 above, water courses are conceived of, not as primary ontological entities, but as three consecutive segments: the fresh water segment, the tidal segment, and the segment constituted by the fresh/salt flow through the lagoon to where it cuts a passage through the reef. (By 'primary' ontological entity, I mean conceptual primitives in this domain - here we will assume that each of the three segments is such a basic conceptual building block in the local ontology.)

Now as Fig. 9 makes clear diagrammatically, each of these three segments has a TOP (nkoo/nkwodo) and a BOTTOM (kn:ââlknapwo). (Once again, we meet the insistent TOP/ BOTTOM opposition, which will be further explained in Section 4.1) These can be thought of as quite precise places - for example, the saltwater reach and the freshwater course often meet in a pebbly bar, which serves as a canoe landing place: the bottom of the mbwaa includes the bar, while the watercourse immediately beneath this is the top of the pye. These terms thus serve as the basis for (descriptive) toponyms: thus Pene mbwaa kn:aa is the name for the bottom of the fresh water river the Pene. 


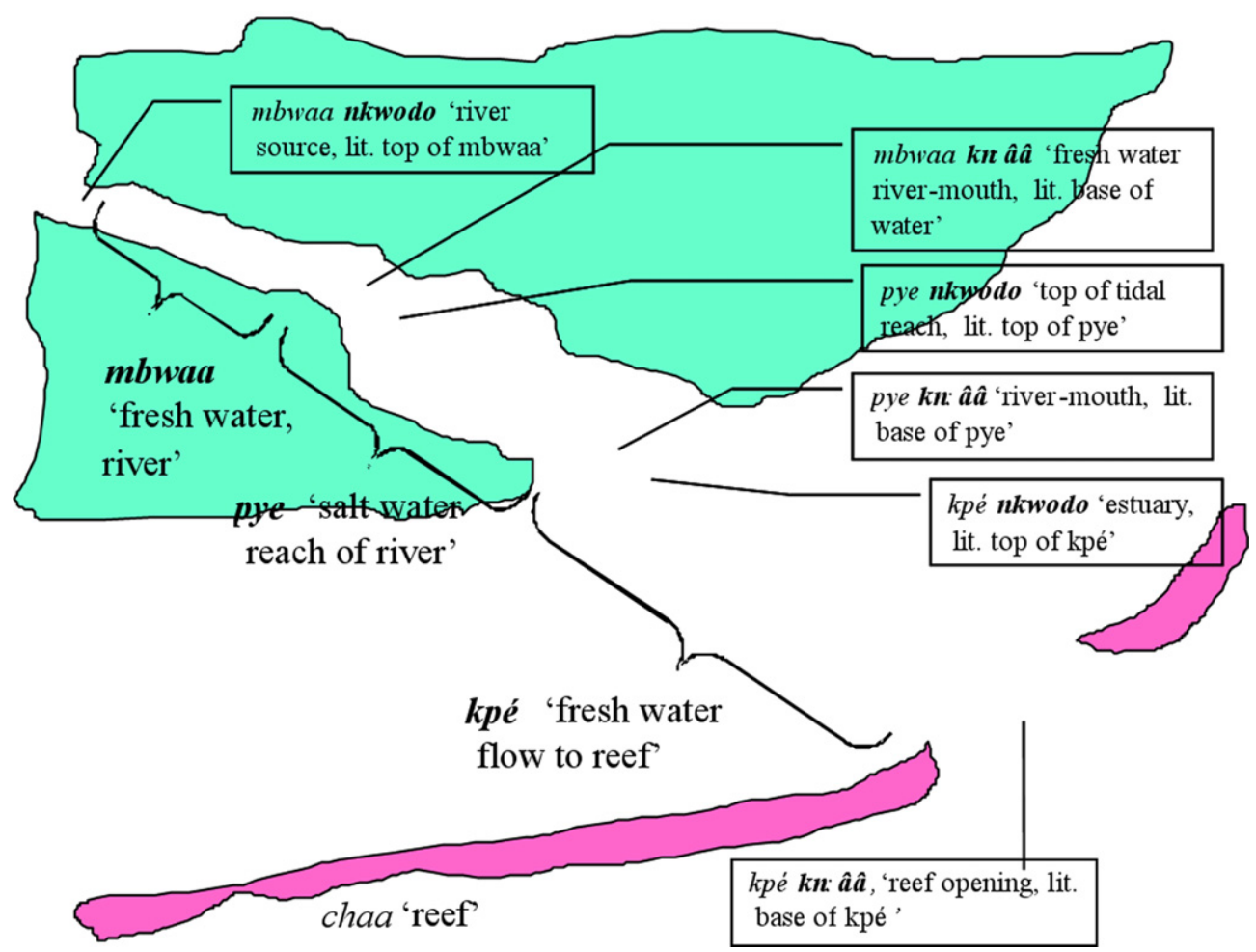

Fig. 9. The conceptualization of a water course as made of three segments, each with a 'top' and 'bottom', which can form the basis of proper names, e.g. Pene mbwaa kn: $\hat{a} \hat{a}$ 'the place at the bottom of the Pene freshwater course'. The whole may (but need not) share a proper name, e.g. Pene mbwaa 'Pene freshwater', Pene pye 'Pene tidal reach', Pene kpé 'Pene lagoon segment of water course'.

In addition, it was mentioned above that all three segments can share a proper name (e.g. Pene mbwaa, Pene Pye, Pene kpé), although often they do not - there may be distinct proper names for each segment. (Or there may be distinct, but related names, as Nyââpu for the freshwater segment, Nyepe for the saltwater reach, and Nyâa for the segment in the lagoon.)

These two facts (a shared paradigm of top/bottom structures, and possible shared naming) suggests that at a secondary, compositional level, the three segments construct a larger secondary or derived ontological entity, which is larger than the English language concept of 'river' since it includes a large section of sea water unbounded by banks.

Table 3 gives the most salient landscape terms for riverine features, with corresponding proper names where I have been able to find them. ${ }^{5}$ Once again, it is clear that there is a very good match between generic feature and specific, named place. In terms of the main motivating factors listed in Section 1.1, the terminology in this subdomain seems mainly motivated by human affordance. For comparison to other systems, note that mbwaa,

\footnotetext{
${ }^{5}$ A reviewer objects to the term 'riverine', as relating too generally to drainage area, suggesting 'hydrological' as the relevant geographical term. But dictionaries list 'riverine' simply as 'of or pertaining to rivers', which is what is intended here, so I retain the common parlance.
} 
Table 3

Riverine features and corresponding proper names

\begin{tabular}{|c|c|c|c|c|}
\hline \multicolumn{2}{|l|}{$\begin{array}{l}\text { Riverine } \\
\text { features }\end{array}$} & \multirow[b]{2}{*}{ Spring, source } & \multicolumn{2}{|l|}{$\begin{array}{l}\text { Corresponding } \\
\text { proper names }\end{array}$} \\
\hline & dpuwó & & & \\
\hline & mbwaankoo dmi & $\begin{array}{l}\text { Sources (lit. 'water top } \\
\text { bundle') }\end{array}$ & & \\
\hline & mbwaa too, рии & Creek & Che puи & \\
\hline & kpo & Confluence & $\begin{array}{l}\text { Lуири Wори уi } \\
\text { кро }\end{array}$ & $\begin{array}{l}\text { The confluence of Lyupu and } \\
\text { Wopu (freshwater) rivers }\end{array}$ \\
\hline & $\begin{array}{l}\text { mbwaa (locative: } \\
\text { mbwaa paa) }\end{array}$ & Freshwater river segment & Wâpu & $\begin{array}{l}\text { This name is restricted to the } \\
\text { freshwater segment }\end{array}$ \\
\hline & mbwaa nkîgh:ê & Banks of freshwater river & & \\
\hline & pye & Tidal river segment & P:uum pye & \\
\hline & kpé & $\begin{array}{l}\text { Lagoon segment of } \\
\text { 'river' }\end{array}$ & Mtyoo & $\begin{array}{l}\text { This name is restricted to the } 3 \mathrm{rd} \\
\text { segment }\end{array}$ \\
\hline & lêe & Pool (river or lagoon) & K:aalêe & $\begin{array}{l}\text { Below Tââchó, gives its name to } \\
\text { area Teelêê-K:aalêê. }\end{array}$ \\
\hline & kpé lêê & $\begin{array}{l}\text { Deep water area in } \\
\text { freshwater river }\end{array}$ & & \\
\hline & nkamê & $\begin{array}{l}\text { Real waterfall (not just } \\
\text { white water) }\end{array}$ & & \\
\hline & lyoko & $\begin{array}{l}\text { Canoe landing, at top } \\
\text { end of tidal segment }\end{array}$ & Téliyé lyoko & $\begin{array}{l}\text { Landing place at Ndâwo near } \\
\text { Mopa }\end{array}$ \\
\hline & $d: \hat{e} \hat{e}$ & Dam & & \\
\hline
\end{tabular}

which also simply means fresh water, canonically refers to the freshwater segment of a river, even if this is dried up (the sense thus includes both our notions 'river' and 'wadi'). Hence the denotation of the term must include the river-bed and the banks up to the normal flood level. ${ }^{6}$ In times of heavy rain, rivulets can run down paths or slopes, but these do not thereby constitute mbwaa, a Rossel fresh water river or stream.

\subsection{Seascape}

Rossel Island is an isolated island at the end of an archipelago. If landscape terms were partonymic (which they only sometimes are), then the unique beginner would be a term for 'world'. The Yélî Dnye term is dyamê, which otherwise glosses as 'island', with the implication that their world is their island Yéli (even though on a fine day the mountains of Sudest, the nearest other island, are visible from the SW of Rossel). In fact, Rossels of course know that there are other islands, and they have proper names for a number of them, such as Wuwo(or Wóó) dyamê 'Misima, lit. coral island', Yamê 'Sudest', Mbwééwo 'Trobriand Islands', and P:aa Lów:a 'Pocklington Reef' (lit. 'upwind Lów:a', where Lów:a is the sacred islet 8 nautical miles to the east of Rossel, and Pocklington, now just a sandbank, lies 100 nautical miles further east) (Table 4).

Rossel Island is set in huge reefs, with a lagoon extending 20 nautical miles west and nearly 10 to the east (to the north and south the reef lies only a mile or two offshore).

\footnotetext{
${ }^{6}$ For $p y e$, tidal segments, these only dry out if a cyclone fills them with washed-down debris. But in that case the water runs fresh, and they become effectively mbwaa, running or dry.
} 
Table 4

Islands/worlds and their names

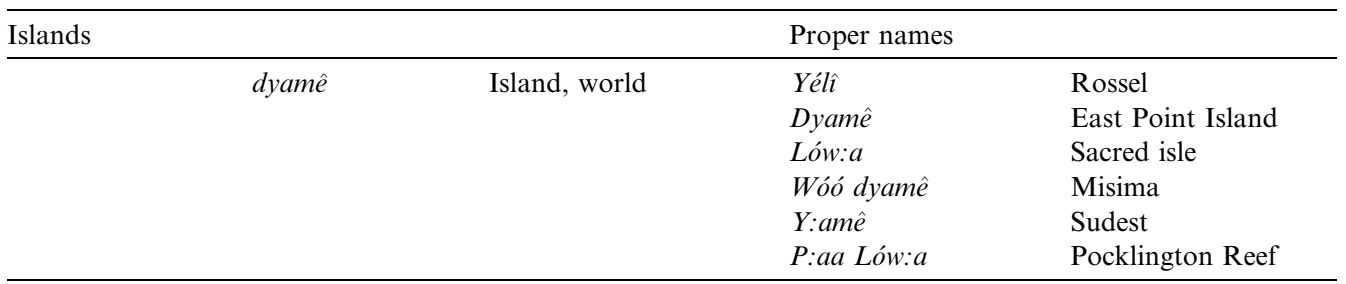

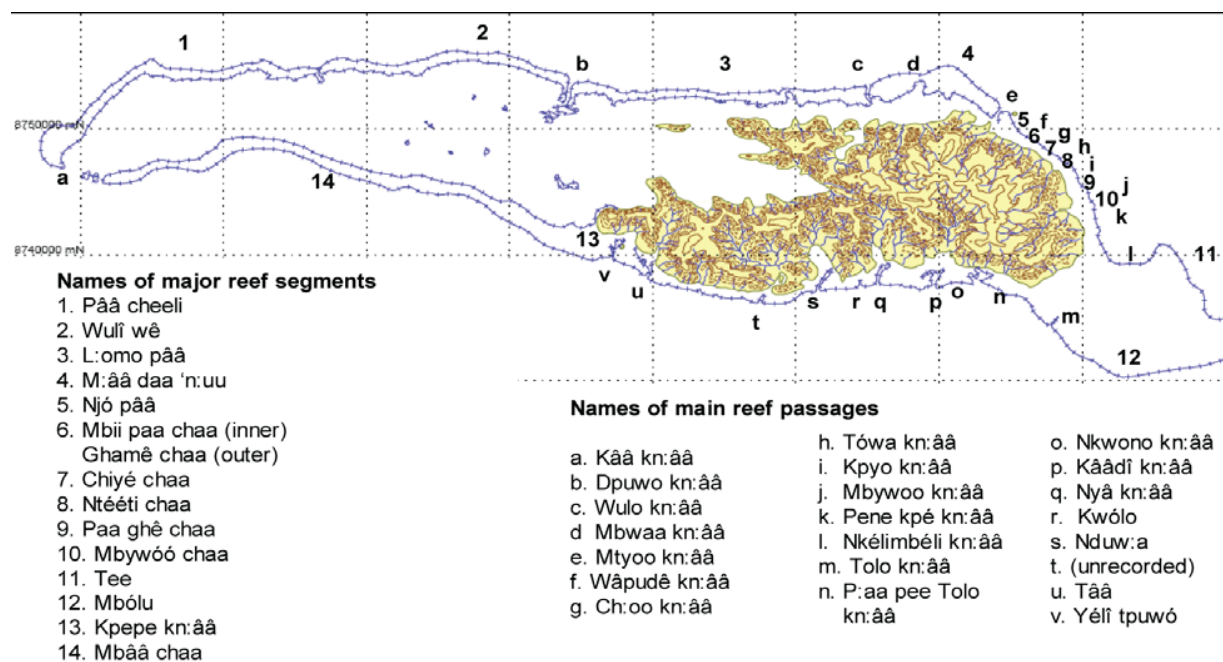

Fig. 10. Named major sections of the barrier reef around Rossel Island (grid in kilometers).

Lagoons have proper names but there is no corresponding seascape term - one of the few mismatches between the two terminological systems, physiographical and toponymic. There are a number of islands and substantial coral outcrops within the barrier reef, all with proper names. And each section of barrier reef, which is segmented by named reef openings, also has a proper name, as shown in Fig. 10.

The seascape inside, on, and outside the reef has entirely different qualities. Water depths inside the lagoons are maximally 34 fathoms $(62 \mathrm{~m})$, and mostly considerably shallower, but immediately outside drop off to 600 fathoms $(1100 \mathrm{~m})$, and a mile or two offshore drop to enormous depths (1000-2000 fathoms, or 1800-3600 m). The seas outside the reef thus run high throughout the season of the SE tradewinds, and currents may run 3 knots or more, while inside although the lagoons can be choppy, only in a high tide or in a heavy storm will a severe swell come over the reef. The two ecologies support different fish, shellfish and other marine life which are the major source of fat and protein for the islanders, who dive and fish on both sides of the reef. This division is reflected in specialized terms for types of water features, although as mentioned there does not seem to be any common noun for lagoon (the nearest is ntii, 'salt-water', and nt:ee 'salt-water Locative' will implicate 'in the lagoon' unless otherwise specified). 
Table 5

Types of salt water or water feature, and corresponding proper names

\begin{tabular}{|c|c|c|c|c|}
\hline $\begin{array}{l}\text { Types of } \\
\text { water } \\
\text { feature }\end{array}$ & Common nouns & Gloss & $\begin{array}{l}\text { Example of } \\
\text { corresponding } \\
\text { proper names }\end{array}$ & Notes \\
\hline \multicolumn{5}{|l|}{$\begin{array}{l}\text { Waters of } \\
\text { the } \\
\text { lagoon }\end{array}$} \\
\hline & $n t i i$ & Salt water & & \\
\hline & $\begin{array}{l}\text { (no common } \\
\text { noun) }\end{array}$ & Lagoon & $\begin{array}{l}\text { Mbéli } \\
P: \hat{a} \hat{a}\end{array}$ & $\begin{array}{l}\text { Eastern lagoon } \\
\text { Western lagoon }\end{array}$ \\
\hline & ch:êênî & $\begin{array}{l}\text { Shallow water of lagoon, light } \\
\text { blue colour, with sandy } \\
\text { bottom }\end{array}$ & D:aa komo & $\begin{array}{l}\text { Near Dyamê island, } \\
\text { East Point, poisoned } \\
\text { for fish }\end{array}$ \\
\hline & chêêlî & $\begin{array}{l}\text { Murky water of lagoon or } \\
\text { estuary, with muddy bottom }\end{array}$ & & \\
\hline & ghodo & Shallow water (puntable) & & \\
\hline & lêe & $\begin{array}{l}\text { Basin, pool, anchorage, } \\
\text { usually with sandy bottom }\end{array}$ & Tââkê lêê & $\begin{array}{l}\text { - Pool inside reef, } \\
\text { turtles really gather } \\
\text { there }\end{array}$ \\
\hline & mbéli & $\begin{array}{l}\text { Deep blue water inside reef, } \\
\text { too deep for punting, with } \\
\text { sandy bottom }\end{array}$ & N:oопu u kwo & $\begin{array}{l}\text { Area west of Mtyoo } \\
\text { passage }\end{array}$ \\
\hline & $\begin{array}{l}\text { (no common } \\
\text { noun) }\end{array}$ & & Y:oo nkigh:e & Name of bay \\
\hline \multicolumn{5}{|l|}{$\begin{array}{l}\text { Waters } \\
\text { outside } \\
\text { the reef }\end{array}$} \\
\hline & kpé & $\begin{array}{l}\text { Deep blue water just outside } \\
\text { reef or in reef passage }\end{array}$ & Pene kpé & Deep eastern passage \\
\hline & kpéé & Water just outside reef (?) & & \\
\hline & mbywémî & Deep blue ocean & kmumw:adówo & $\begin{array}{l}\text { Name of sacred place } \\
\text { (in ocean, near } \\
\text { Motorina) }\end{array}$ \\
\hline & mbywémî w:êmî & Sea far from shore & & \\
\hline & mbywémî kpâpu & Really deep sea & & \\
\hline & ngomo & Open ocean & & \\
\hline & mgêênî & Current & Po & $\begin{array}{l}\text { Named current in } \\
\text { eastern lagoon }\end{array}$ \\
\hline
\end{tabular}

Table 5 shows the major distinctions between types of salt-water region, which have to do with, first, occurrence within or outside the reef, second, with distinctions in depth and clarity of the water, and thirdly with properties of the bottom. Many of these water types are shown diagrammatically on the cross-section of the lagoon in the top panel of Fig. 6 above. The other water-types outside the reef seem to be distinguished largely by how far off-shore the waters lie. Mbywémi for example can be qualified according to how far it is from shore, and the consequent size of swell (mbwémi kpâpî lit. 'ocean ridges'), while ngomo seems to indicate areas of the ocean outside the influence of land altogether where the full force of the swell is unmitigated. Unlike the Trobrianders (see Senft, this issue) and 
Table 6

Structural features of the lagoon

\begin{tabular}{|c|c|c|c|c|}
\hline $\begin{array}{l}\text { Features of } \\
\text { the lagoon }\end{array}$ & $\begin{array}{l}\text { Common } \\
\text { nouns }\end{array}$ & Gloss & $\begin{array}{l}\text { Corresponding } \\
\text { proper names }\end{array}$ & notes \\
\hline & $\begin{array}{l}\text { dóó kpâpu } \\
\text { wuwo }\end{array}$ & $\begin{array}{l}\text { Area of seaweedy hillocks } \\
\text { Coral rock }\end{array}$ & $\begin{array}{l}\text { Wââvyuwo } \\
\text { Yidika }\end{array}$ & $\begin{array}{l}\text { East of Wââpudî kn:ââ } \\
\text { Name of sacred rock on reef } \\
\text { flat }\end{array}$ \\
\hline & $\begin{array}{l}\text { wuwo } \\
w: u u\end{array}$ & Coral heads & Ghênê & $\begin{array}{l}\text { Name of coral head in } \\
\text { Western lagoon, near Wulî } \\
\text { Island }\end{array}$ \\
\hline & $\begin{array}{l}\text { ghaa } \\
\text { dyêêdî }\end{array}$ & Shoal or inner reef & & \\
\hline & chii lêê & $\begin{array}{l}\text { Natural pool used to } \\
\text { poison fish }\end{array}$ & Kitivyuwo & Near Pene passage \\
\hline & $k a a$ & $\begin{array}{l}\text { Fish trap made of coral } \\
\text { boulders in tidal zone }\end{array}$ & $\begin{array}{l}\text { (Sometimes named } \\
\text { after their makers) }\end{array}$ & \\
\hline & kêmina & $\begin{array}{l}\text { Large V-shaped coral } \\
\text { fishtrap on outer reef flat }\end{array}$ & & \\
\hline & kmuwó & $\begin{array}{l}\text { Artificial island used for } \\
\text { fishing }\end{array}$ & Queensland! & \\
\hline \multirow[t]{8}{*}{$\begin{array}{l}\text { Shore } \\
\text { features }\end{array}$} & téma & $\begin{array}{l}\text { Beech landward of } \\
\text { mangroves }\end{array}$ & & \\
\hline & ghêêd $\hat{\imath}$ & $\begin{array}{l}\text { Mangrove belt (also name } \\
\text { of a mangrove species) }\end{array}$ & $W: \hat{e} e \hat{d} d a$ & East of Yâpwo \\
\hline & dêma & Bay in mangroves & & \\
\hline & $\begin{array}{l}\text { tii pââ } \\
\text { tii mbwó }\end{array}$ & $\begin{array}{l}\text { Beach } \\
\text { Sand bank }\end{array}$ & Ntapê tii & Beach near Yâpwo \\
\hline & $\begin{array}{l}\text { lyoko } \\
\text { kmuu }\end{array}$ & $\begin{array}{l}\text { Canoe landing place } \\
\text { Shell midden }\end{array}$ & Cheme lyoko & \\
\hline & $\begin{array}{l}\text { 'nuwo } \\
\text { mbwéédi }\end{array}$ & $\begin{array}{l}\text { Point, promontory } \\
\text { Muddy area }\end{array}$ & Yélî 'nuwo & East point \\
\hline & $\begin{array}{l}\text { chêêp } \hat{\imath} \\
\text { t:aanî }\end{array}$ & (Volcanic) rocks & Mbaati & Sacred rock \\
\hline & & & K:aa chimi knî & Sacred rocks \\
\hline
\end{tabular}

other Austronesian-speaking peoples, Rossel people at the time of colonial contact were not ambitious navigators - their major foreign ventures were only to the island immediately to the West (Sudest). ${ }^{7}$ As shown by Senft, the Trobrianders have a much more developed terminology for the outer ocean areas. Note though, that like the Trobrianders, Rossels name specific ocean currents: thus Pyiy:e mg:êenti is the name of a current that runs from offshore of the Mbaati sacred place (with which it is mythologically associated, see Section 4.2) for nine nautical miles due southeast along the reef, before doing an abrupt turn north.

In the table, the reader will notice that, again, many of these types of water area have corresponding proper names, sometimes of quite small extent. Note that the proper name for the Eastern lagoon is Mbéli, which is also the common noun term for deep blue water

\footnotetext{
${ }^{7}$ But myths link the origin of Rossel people to the submerged island (now the sandbank Pocklington Reef, known as P:aa Lów:a) over 100 nautical miles to the east, suggesting greater nautical skills in much earlier times, and showing that they certainly knew of its existence. Pocklington would have been a large island about 8,000 years ago when sea levels were much lower - still it would, by virtue of a narrow shape, have offered a slim target for navigators, who moreover would have had to sail against the prevailing winds.
} 
Table 7

Reef structures and corresponding proper names

\begin{tabular}{|c|c|c|c|c|}
\hline \multicolumn{3}{|l|}{ Reef passages } & \multicolumn{2}{|l|}{ Proper names } \\
\hline Passages & $\begin{array}{l}\text { kpé } \\
k n: a ̂ a ̂ a\end{array}$ & Major reef passage & Pene kn:ââ & $\begin{array}{l}\text { Particular passage } \\
\text { (bottom of a watercourse) }\end{array}$ \\
\hline & & & $\begin{array}{l}\text { tpile pê kpé } \\
\text { 'Snake Passage' }\end{array}$ & $\begin{array}{l}\text { Between Sudest and } \\
\text { Rossel }\end{array}$ \\
\hline & dédi maa & $\begin{array}{l}\text { Small reef passage } \\
\text { navigable by canoes }\end{array}$ & Limiyó & Near Cheme passage \\
\hline & $\begin{array}{l}\text { k:ane I } \\
\text { ke'ne }\end{array}$ & $\begin{array}{l}\text { Artificial reef opening } \\
\text { for canoes }\end{array}$ & & \\
\hline \multirow{13}{*}{ Reef structures } & chaa & Reef of any kind & & \\
\hline & chaa pââ & $\begin{array}{l}\text { Reef segment between } \\
\text { passages }\end{array}$ & Mtênê Ghama & Sacred outer reef \\
\hline & & & Njóó pââchaa & $\begin{array}{l}\text { Reef between Cheme and } \\
\text { Mtyoo passages }\end{array}$ \\
\hline & & $\begin{array}{l}\text { Reef part with } \\
\text { associated shallows }\end{array}$ & Pââcheli & $\begin{array}{l}\text { Sacred section at far west } \\
\text { lagoon }\end{array}$ \\
\hline & wuwo & Coral boulders & & \\
\hline & w:uu & & & \\
\hline & dp:iipee & Underwater cave & & \\
\hline & pyungo & Deep blow hole & & \\
\hline & dpada & $\begin{array}{l}\text { Reef platform (mostly } \\
\text { dead coral) }\end{array}$ & $\begin{array}{l}\text { Chaa kwéli pwaa } \\
\text { wo }\end{array}$ & $\begin{array}{l}\text { Portion of dpada (lit. } \\
\text { 'where the reef broke') }\end{array}$ \\
\hline & ghee & Corner of reef passage & Km:êmî km:ee & Portion of dpada at \\
\hline & komo & & & Wâpudî kn:ââ \\
\hline & $m: a \hat{a}$ pââ & Dry reef (at low tide) & & \\
\hline & $\begin{array}{l}\text { chaa } \\
\text { kuwa }\end{array}$ & Reef face & & \\
\hline \multirow{2}{*}{$\begin{array}{l}\text { Other structures } \\
\text { occurring on reefs }\end{array}$} & dyamê & Island & & \\
\hline & tii mbwó & Sand bank & & \\
\hline
\end{tabular}

inside a reef (the Eastern lagoon is to the contrary remarkable, to the outside observer anyway, for the extent of its ch:êen î or light blue, relatively shallow, water indicative of a sandy bottom).

Turning now to features of the lagoon that are more directly linked to underlying physiography (coral structures, sand banks, etc.), we find that there are many terms specialized to features of the lagoon, as shown in the table below (Table 6).

The reef structures themselves are of enormous importance - meteorological (since they hold back storm surges) and economic. Walking and fishing on them at low tides provides the best chance for protein. Table 7 gives some of the landform terms for parts of the reef and its special structures. As shown in Fig. 9 earlier, the reef itself is segmented by reef passages (kpé kn:ââ), which are deep, narrow (ca. 100-200 m) openings to the lagoon: they are cut either by a river flowing into the lagoon at the shore, or by riptides caused by other means. They all have proper names, and are conceived of as part of the watercourse system, which was described above in Section 3.3. These watercourses cut the barrier reef into segments of reef or chaa, each named, as also shown earlier in Fig. 10 (20 major named sections are shown, but there are also names for parts of them). Also on the reef are named sacred places, further explained under that rubric in Section 4, ensuring that there are many proper names for sea areas. 


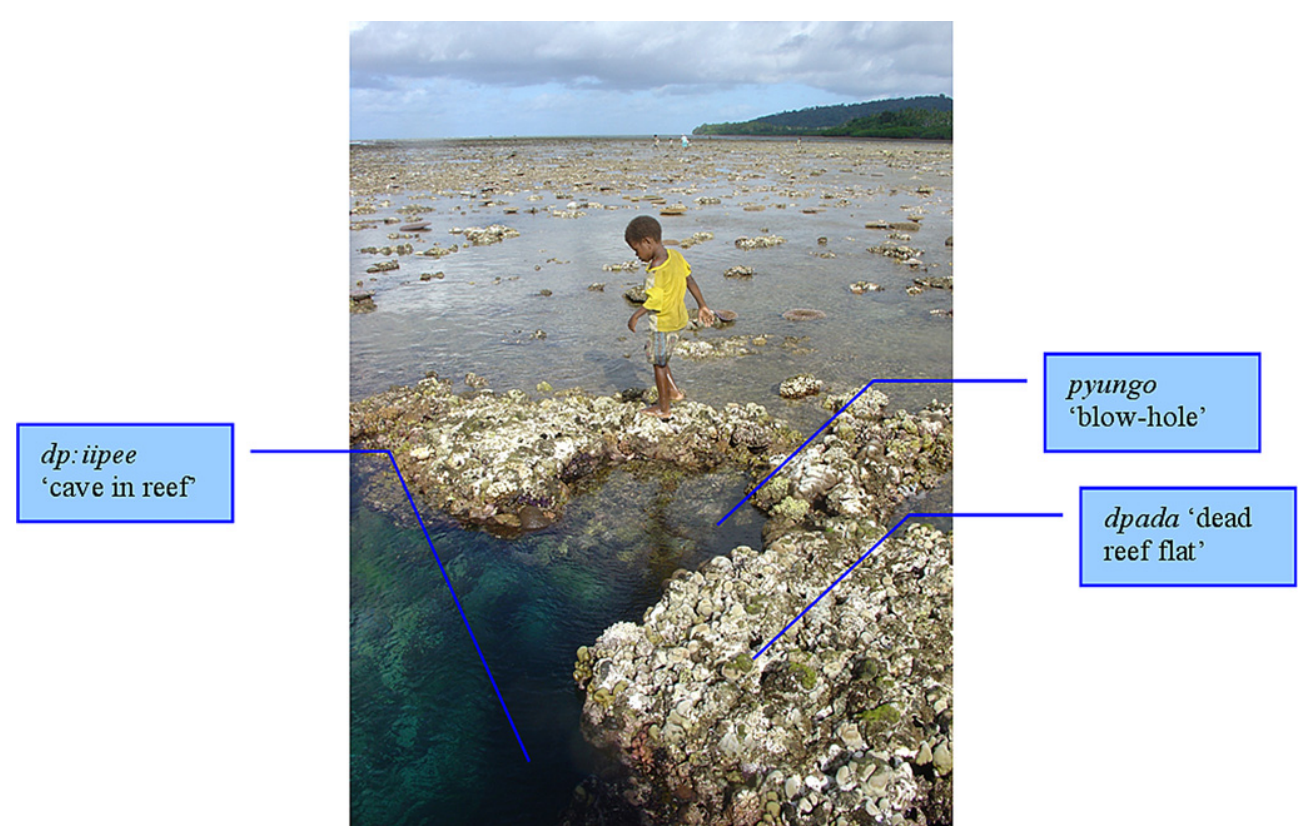

Fig. 11. Boy searching for shell fish on edge of the reef.

The reef also has a rich and economically important microstructure, with names for recurrent features, as illustrated, for example, in Fig. 11, which shows features near the seawards edge of a reef.

Although it is not so surprising that a people who forage virtually all their protein from the sea would have a rich marine feature terminology, it does not follow from this that many such features need have proper names. However, there is a great density of toponyms for the foreshore, lagoon areas, and the reef structures themselves. Goodenough (1951) documented a similar density of marine toponyms for Truk, where kin-based ownership of fisheries seems to have been the major motive. On Rossel, there is ownership in principle of lagoon and reef areas, but in complex ways. First, matriclans have abstract 'ownership' of (ca. $2 \mathrm{~km}$ wide) strips of real estate that stretch from the central mountains out to sea. Matriclan rights have to do especially with control of sacred places on land, in the lagoon or on the reef. However, practical usage rights reside with local area groups, where the main recruitment is by patrilineal descent (since residence is virilocal), and the areas claimed are usually one segment of reef between watercourses. People without rights can fish the reefs, but they should hand over a portion of their catch to the owners. All these kinds of rights and obligations do indeed motivate a rich toponymy of the seascape. Figs. 12 and 13 illustrate this parallel between descriptive and proper names on a 3$\mathrm{km}$ stretch of coastal water.

\section{The role of cultural factors in landscape ontology and toponyms}

Let us return once again to the questions raised in Section 1.1 about the three major factors that may motivate categorization in this domain, namely perceptual salience, 


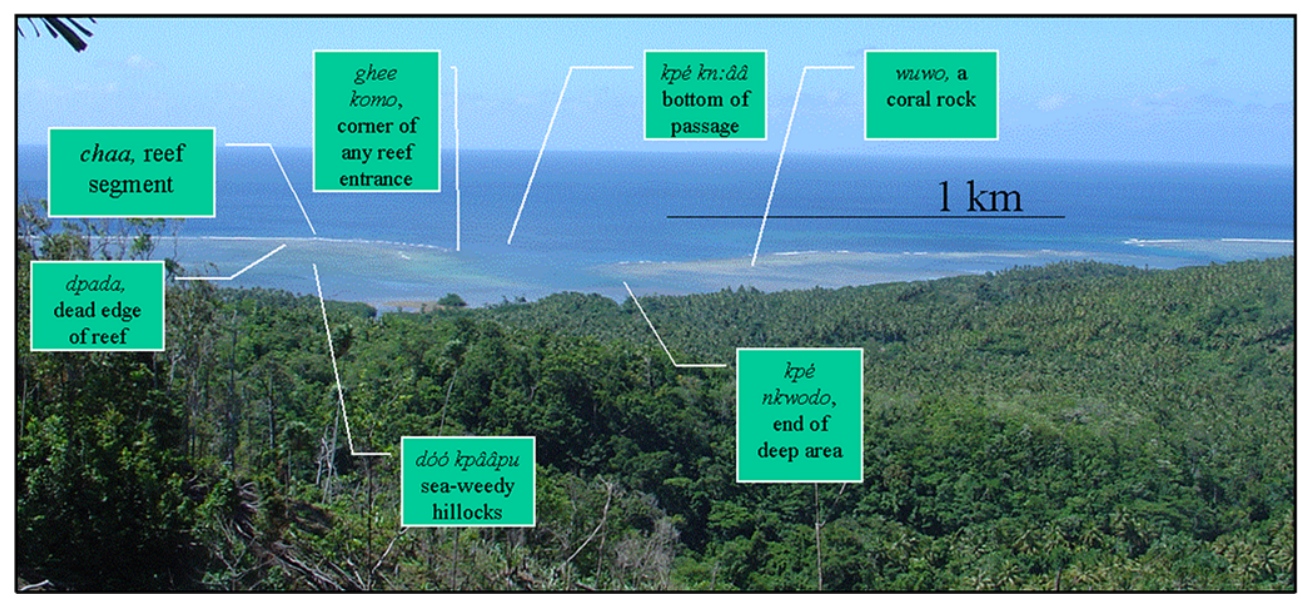

Fig. 12. Common nouns denoting major reef features. The photo shows a $3 \mathrm{~km}$ stretch of coast off the NE end of the island.

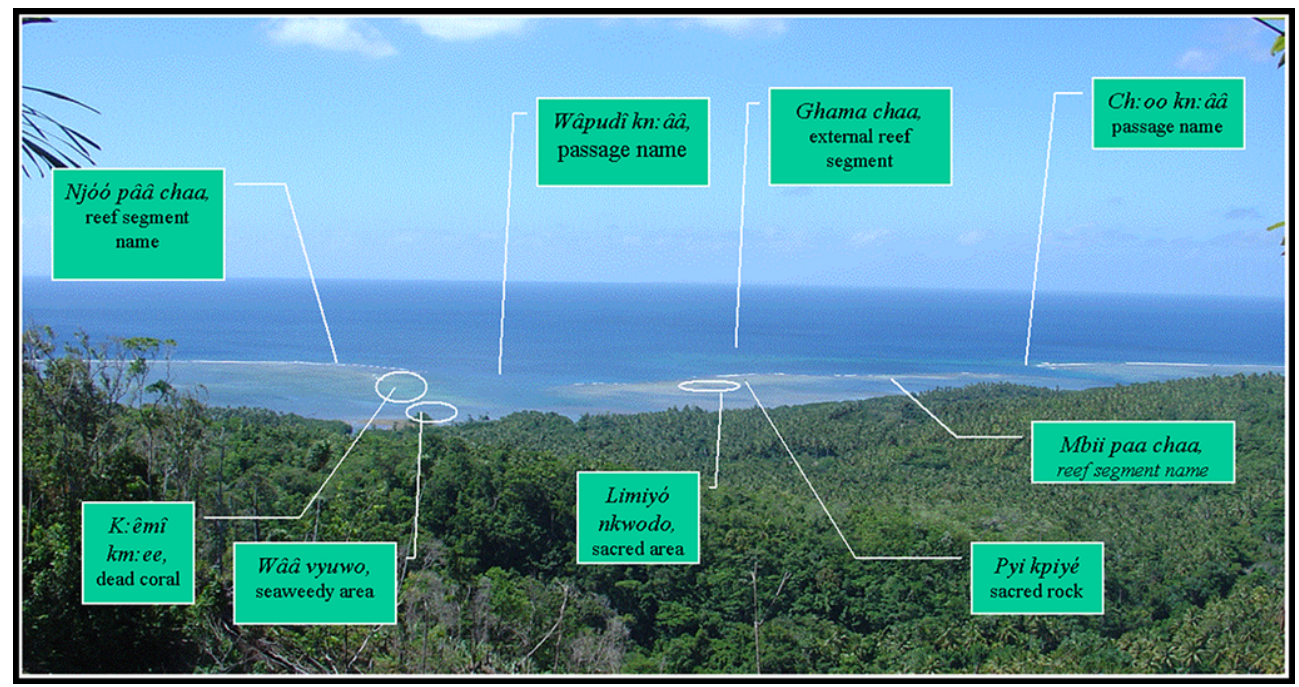

Fig. 13. Proper nouns naming some major reef features on the same stretch of coast.

human affordance or utility, and cultural factors. So far, apart from the occasional case like $m b u$, where pure perceptual factors seem prominent, human affordance and utility seems to be at work. For example, the categorization of seascape features seems largely driven by their importance in fishing or boat transport, although in many cases this accords with major perceptual discontinuities (e.g. breaks in the reef, or qualities of lagoon bottom).

However, cultural factors of different kinds are also of considerable importance. In this section we explore three of these. First, there is the obvious case of man-made landscape features (Section 4.1). Second, and more interesting, there is an implicit cultural template, or cultural model, that operates in a parallel way across different domains like landscape 
elevations and seascape features, providing a conceptual model that structures both the ontology of categories and the specifics of toponyms. Thirdly, the indigenous religious and mythological system provides an association between places and gods that has practical implications for land use and toponymy. We review them in turn.

\subsection{The works of man}

So far we have largely been considering how natural features get conceptualized for description and naming. Natural features rarely have sharp boundaries: rivers shrink and expand according to season, mountains grade into foothills, and ridges flow into the flanks of mountains - the geophysical world is, as we noted, a continuous surface. But humans find it useful to invent and name specific areas or regions (cf. parishes, counties and the like), thus yielding a patchwork of named areas in which places or things or persons can be located. These are mental constructions, often riding over features that might offer discontinuities (rivers, ridges, etc.).

Rossel Island is segmented, first, into a systematic set of matrilineal clan areas, each clan being virtual 'owners' of a strip of land from cordillera to reef. These may be partially discontinuous territories, because a clan may 'own' a sacred place in another clan's territory (see Levinson, 2006, for the details). Second, there are areas based on patrilineally related hamlets, since residence and practical land ownership (usufruct) are inherited patrilineally. These form effective administrative and judicial units. Beneath these are many smaller areas, based on the names of paths, rivers, villages, etc., which nest up to three units deep, as shown schematically in Fig. 14. The general term for an area is wee, as reflected in the proper nouns in the figure.

As shown in Fig. 14 and Table 8, a region of any substantial size (say, over a square kilometer) is a wee, and to these there correspond proper names which may or may not include the word wee. Small areas may be designated kêeli ghi, and these too may be named. There are many hundred such names on Rossel for areas, nested by inclusive size

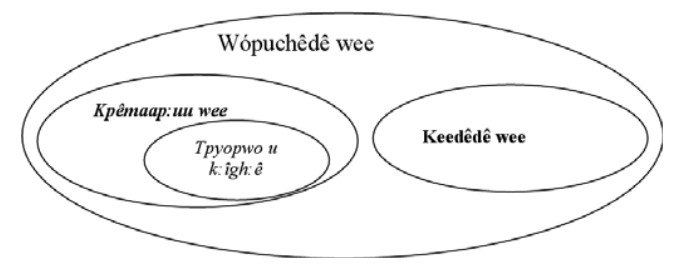

Fig. 14. Schematic diagram of nested named areas.

Table 8

Illustrative district names

\begin{tabular}{|c|c|c|}
\hline Area names & Common noun & Proper names \\
\hline & \multirow[t]{3}{*}{ wee 'district, region' } & Daa (P:uupaa area, origin of Daa clan) \\
\hline & & Ghomo (area name inland of Mbâânuwo) \\
\hline & & Mbwaa Paa wee (Mbwaa river-bank area) \\
\hline & $\begin{array}{l}\text { kêêlî ghi 'small area' (lit. 'between } \\
\text { parts') }\end{array}$ & $\begin{array}{l}\text { Anté wulo wono (small area of river flat near Wópu } \\
\text { river) }\end{array}$ \\
\hline
\end{tabular}


Table 9

Man-made features and their names

\begin{tabular}{|c|c|c|c|c|}
\hline Manmade & Common noun & Gloss & Proper name & (examples) \\
\hline & p:aa nkîpwi & Abandoned village site & $\begin{array}{l}\text { Mbaa chóó, } \\
\text { Kiivyuwo }\end{array}$ & \\
\hline & ngomo & House & & \\
\hline & chêêpi kaa & Raised stone platform, forum & & \\
\hline & chêêpî liy:a & Stone terracing (ancient) & & \\
\hline & yâpwo têdê & Garden & Dmyiniyichó & Raymond's garden \\
\hline & kêêpî & $\begin{array}{l}\text { Previous garden site, recently } \\
\text { used but abandoned }\end{array}$ & Nkene paa & $\begin{array}{l}\text { Kennis Kaambwa's old } \\
\text { garden, near Wópu river }\end{array}$ \\
\hline & $k p \hat{e}$ & $\begin{array}{l}\text { Plantation of palms - sago, } \\
\text { coconut, betelnut }\end{array}$ & $\begin{array}{l}\text { (see Section } \\
3.2)\end{array}$ & \\
\hline & maa & Path & Wódu nyedê & Path from Jinjo to Abaleti \\
\hline
\end{tabular}

(see Basso, 1984, for an analogous case). All these areas are places where specific persons have rights, either of an abstract spiritual kind by matrilineal descent, or of a practical usufruct type based on virilocal residence.

In addition to these humanly conceived administrative or legal areas defined by fiat, there are of course man-made or built features. Rossel villages consist of one or more hamlets, each with half a dozen houses for extended families. Rossel houses are built of perishable bush-materials, and little remains of a village after it is abandoned (usually after a few generations) except the domesticated palms and other cultivars like mango trees. More lasting are the stone platforms that were built in the centre of a village for male pow-wows, and stone terracing of gardens that used to be used by mountain villagers. Other ancient stone structures are attributed to the gods. A major long-lasting feature, however, are the paths or maa that criss-cross the island, linking villages along the coast or over the mountain ridges (see Fig. 8 above). Because of their utility in the absence of any wheeled transport or reliable power boats, these are mostly maintained through the jungle simply by passage, and occasionally by work party. However, some of the ancient pathways over the mountains were destroyed by cyclone Justin in 1997, which caused many major landslides and felled thousands of giant trees across the paths.

Table 9 lists some common and proper names for man-made features. Other man-made features of note are the changes in vegetation that mark old gardens and old village sites, already described in Section 3.2 above. Note that gardens and paths can have proper names that are simplex, without a descriptive reference to their kind of landscape feature.

\subsection{The works of the gods: when places are deities}

In the first (and only) ethnography of Rossel Island, Armstrong (1928) listed 52 major sacred places or yâpwo. In addition to these there are countless minor ones, sometimes consisting of a single tree or rock. Major yâpwo may be whole islands or mountains (as with the highest mountain $M g \hat{\imath})$, or consist of a square kilometer of prime coastal land 


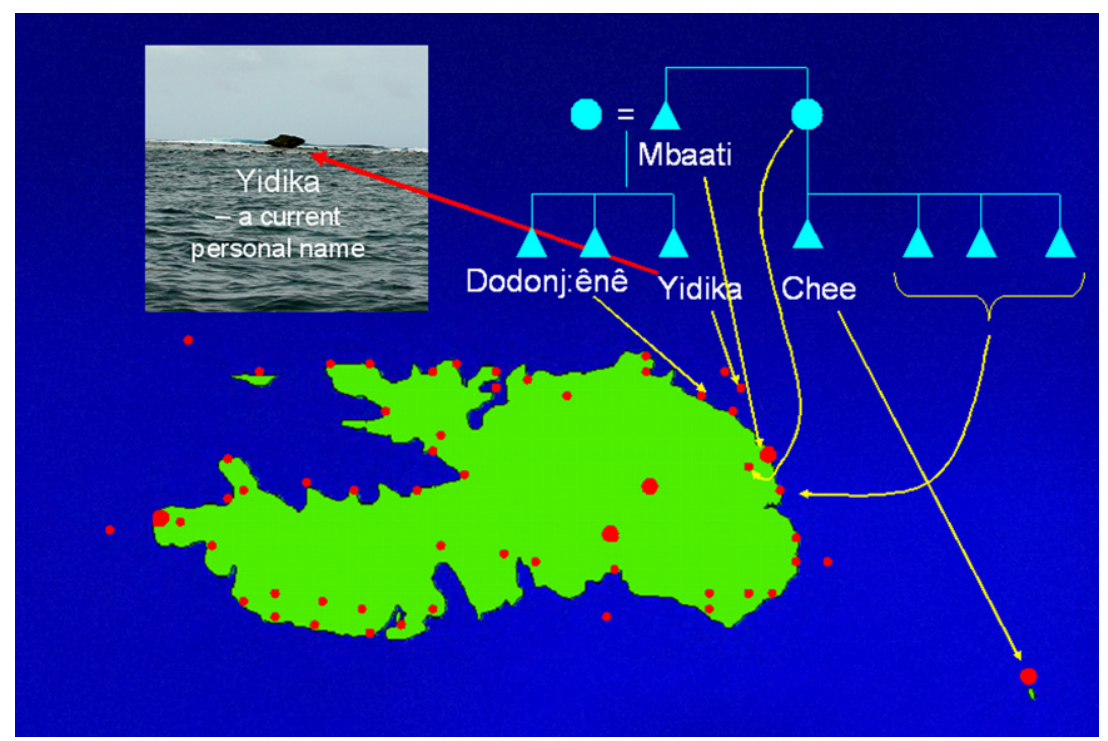

Fig. 15. The major sacred sites (yâpwo) of Rossel Island. The kinship diagram shows the sons and nephews of Mbaati, the major culture god of Rossel, and the arrows show the sites identified with each of these minor gods. Inset is a photo of the rock called Yidika, instantiation of one of Mbaati's sons - Yidika is a current personal name, illustrating how religious beliefs can make a place have a personal name.

where no unauthorized person may tread - in general they are surrounded by tâa or virgin rain forest, constituting important nature reserves. However, there are also numerous offshore yâpwo, some in the lagoon, others on the reef, and yet others on small islands. Fig. 15 gives an impression of the distribution of the major 50-odd yâpwo.

Superimposed on the figure is a family tree focussed on the important god Mbaati, who is credited with bringing the cultivars to Rossel. The arrows show how a cluster of neighbouring sacred sites are sacred to Mbaati, and his sons and nephews, who are all minor gods in themselves.

A yâpwo is not just a sacred site like Mecca or St Peters giving heightened access to spiritual power. For in the Rossel case, the place itself $i s$ the god, in his landscape avatar. The place name can thus also denote the God: for example, Mount Rossel or $M g \hat{\imath}$ is the home of Peede, the otiose Rossel high god, ${ }^{8}$ and together with the surrounding peaks is called Mgî chimi knî, 'Mgî with his nephews'. Fig. 16 shows how the peaks of the highest mountain chain, already familiar from Fig. 4, instantiate Peede and his close relatives.

The Rossel pantheon is large and reminiscent of the classical Greek Olympiad, with a family of major gods with many foibles, and also numerous lesser semi-mortal legendary heroes (cf. Herakles), all of whom have at least one incarnation in a place. Important sacred places have priests or custodians (yâpwo chóo 'owner of sacred place'), who have secret chants that allow them to enter the sacred site with impunity. Other persons, exclusively male, may enter only in the priest's company. In some sacred sites, especially the mountain Mgî and the isle of Lów:a, special taboo vocabularies must be used instead of

\footnotetext{
8 'Otiose god' is an anthropological term for an indigenous principle deity who is inert and above bothering with human affairs. Incidentally, gods often have multiple names in accord with their shifting avatars.
} 


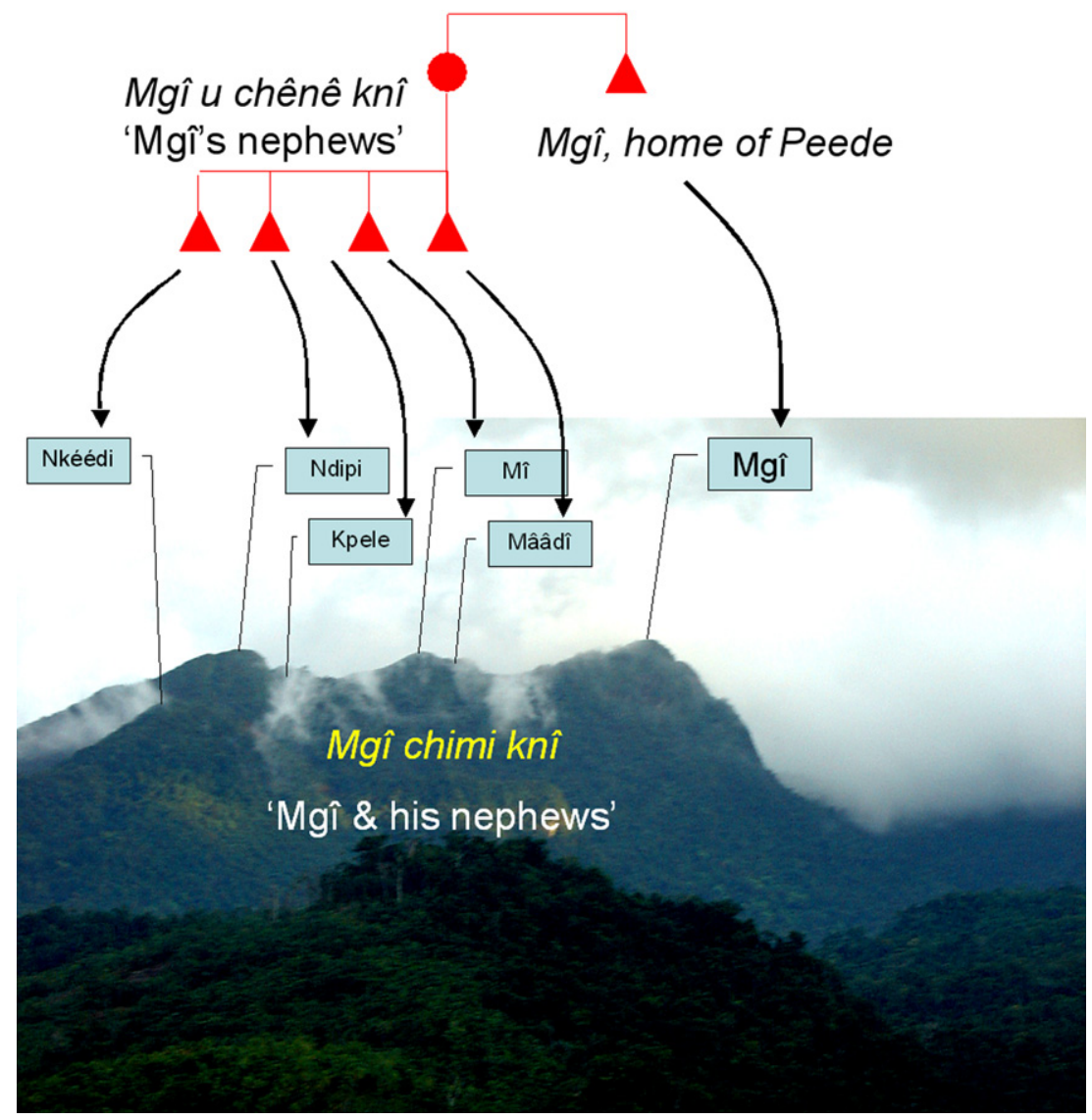

Fig. 16. Mount Rossel ( $M g \hat{\imath})$ and neighbouring peaks as Peede and his nephews. Peede is otiose high god of Rossel. The figure shows how toponyms can be the personal names of gods.

ordinary language. Here I give details of two important sacred places, the Mbaati yâpwo and the isle of Lów:a.

Returning to the god Mbaati, his yâpwo, normally known simply as Yâpwo or as Yââmêne, is one of the most important on Rossel. Mbaati is a culture hero, who arrived from Sudest in a sailing canoe, bearing the dog, the pig and taro. His sacred place is a square kilometer of virgin forest on the northeast coast of Rossel, which contains a number of important sacred sites (see Fig. 17). ${ }^{9}$ The site is entered, in the company of a priest singing sacred songs, by leaving the canoe at a designated place (Kimivyuwo), where a sacred path (called D:aa maa) leaves for the central shrines. Mbaati's own incarnation is a rock just offshore in the lagoon which can only be climbed on by the priest, who has to clean it of driftwood to avoid the cyclones that would otherwise ensue. A creek called K:eetoo puu flows just behind the rock into the lagoon - its waters, like those of the Styx, are held to be a deadly drink. On either side of the creek are two small stones (called Yâan:êê dê

\footnotetext{
${ }^{9}$ A great deal of information on this and other sacred sites was published by Armstrong (1928); in prior times, this kind of information would have been at least partly esoteric knowledge.
} 


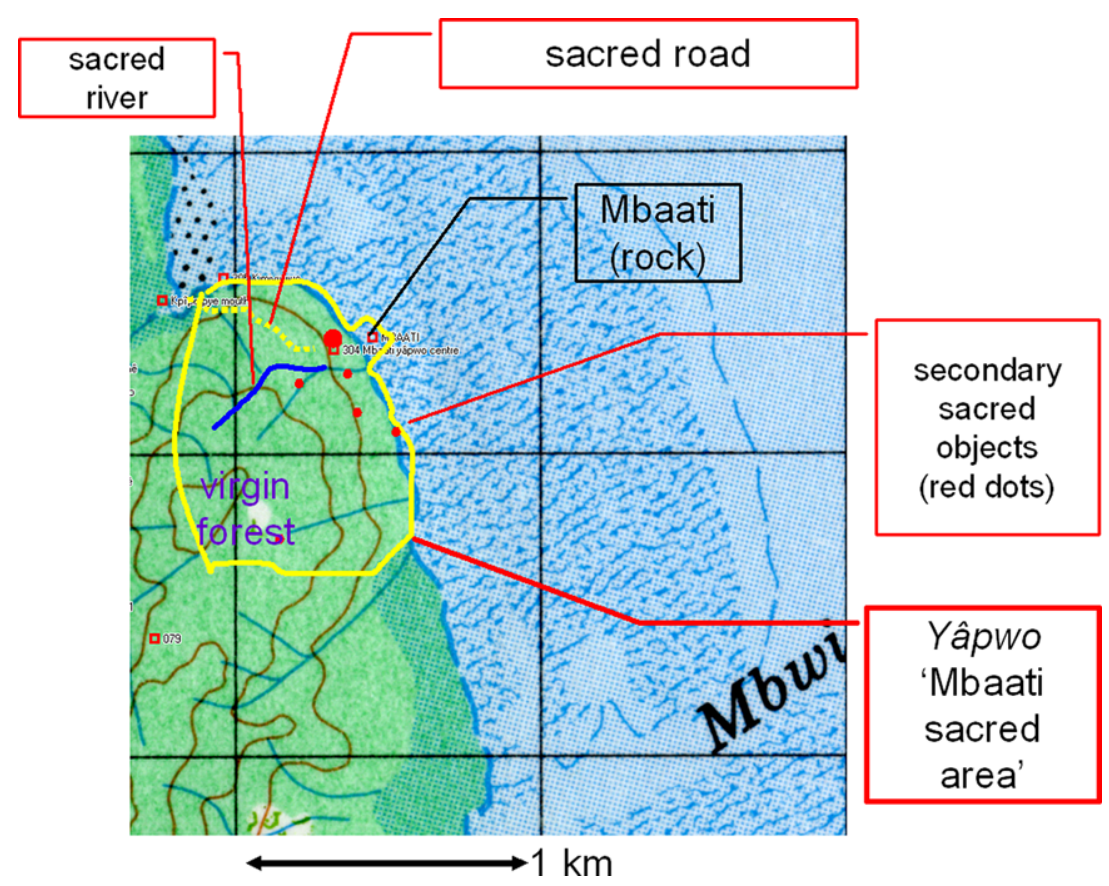

Fig. 17. The sacred topography of the Mbaati yâpwo. Nearly a square kilometer of virgin forest encloses half a dozen sacred rocks and other sacred elements. Mbaati himself is instantiated by a rock just offshore, in front of the mouth of a sacred river with poisonous water. Supplicants approach the site along a sacred road, reached from a canoe landing place. All these entities bear toponyms.

'the two bits of Yââ'), reddened with ochre, which can be used to increase the warmth of the sun during the agricultural cycle. Elsewhere in the jungle are further sacred sites, including the Ur cultivars Mbaati brought to Rossel, his wife who laid the egg from which mankind sprung, and further rocks representing the genitals which control venereal disease. On the sacred road lies a rock incarnating Mbaati's predecessor, an indigenous Mbaati, now superseded. Casual trespass in these areas, or failure to clean them, will bring calamities (cyclones, crop failure, epidemics, etc.) to Rossel.

The sacred isle of Lów:a lies about $16 \mathrm{~km}$ offshore to the east of Rossel, at the head of the eastern lagoon. It is about half a kilometer across, forested with salt-tolerant species and coconuts. Three matrilineal clans have claims to it on mythological grounds. Only men may land on Lów:a, and should then use the taboo vocabulary (ca. 50-100 substitutes for common words) special to the island. Lów:a is home to two important gods, and is visited by many others, all incarnated in specific stones or areas. The two main residents are (i) Yee, an evil god, who had incest with his sister, killed her, and invented cannibalism, and (ii) Laapî, a goddess who takes the form of a huge octopus (and also a crab), a potentially dangerous siren who can seize vessels and wreck them on the island, but is also responsible for the alternation of the monsoon seasons.

Yee is incarnated in a small black rock on a large coral boulder called Yee's house near a freshwater spring at the centre of the isle. He is also incarnated in a giant sea eagle (maalî, Haliaeetus leucogaster) that has always been resident with his mate on Lów:a (the ecology is perfect habitat). Laapî has a sacred area in two small bays on the SW of 
the isle, where no one may fish. She controls the SE tradewinds, while her husband Kpiyé, with moray eel avatar, controls the NW wind season - his sacred place is far to the west of Rossel on the northern reef. Laapî restlessly rearranges the sand banks to the NE of the isle, and it is here that she seizes vessels (there are about half a dozen wrecks on the surrounding reefs). Most of the taboo vocabulary associated with the isle derives from her myths - e.g. the number seven is replaced because she has seven arms. Most of the features of the sacred isle of Lów:a, spits, bays, rocks and so on, are associated with other gods and the springs on Lów:a are said to directly connect to $M g \hat{\imath}$, the Olympic residence of the high god Peede and his associates.

These two vignettes give some idea of the nature of sacred places, which are dotted around the whole of Rossel and its reefs. They play an important ecological role, restricting land and sea use. Their existence has as consequence that a number of toponyms are also personal names, for places are often gods. These beliefs also have the consequence that particular stones, reefs, pools, trees or landscape features, otherwise unremarkable, may be singled out by proper names.

\subsection{Conceptual templates}

A number of authors have found cultural templates or schemata that underlie thinking across the spatial domain, for example application of a model of a 'tilted world' (Brown and Levinson, 1993, re Tzeltal), or 'slope gradient' (Levinson, 2003, re Guugu Yimithirr), or a model of a 'radial world' (Bennardo, 2005, re Tonga), or a fractal model of a quadruped mapped onto drainage patterns (Burenhult, 2005, this issue, re Jahai). When analysts discover these patterns they get a 'eureka experience' - suddenly many diverse cultural details fall into place in an organizing frame.

An important frame of this kind on Rossel is made explicit in organized vocabulary sets, sets of opposed verbs, and sets of nouns. First, there are sets of verbs in systematic opposition which presume the topography of a hill or ridge. Stories are replete with expressions of the kind 'go up', 'follow up (e.g. a ridge or stream)', 'carry something up' and their converses 'go down', 'follow down', 'carry down'. When you get to the top, you 'go over', 'cross (the ridge/pass/summit) over', and 'carry over'. There are here three directions: up, over, down. And three distinct verb types: intransitives, 'landscape transitives' where the direct objects are landforms traversed (as in 'follow up a ridge', 'cross a pass'), and 'take transitives' (as in 'take something up', 'carry someone over'). There is an almost perfect paradigm of oppositions as in Table 10, with application to a simple landscape feature like a hill sketched in Fig. 18.

Now many of these same oppositions, sometimes with specialized verbs in bold below, have application to rivers, or rather the three segments of watercourses, as in Table 11. Fig. 19 illustrates the application to a water course - recollect that water courses are

Table 10

Paradigm of semantic oppositions encoded in verbs of motion

\begin{tabular}{llll}
\hline Direction & Intransitive & Landscape transitive & Take transitive \\
\hline UP & kee 'go up' & vy:uu 'climb something' & $k m: \hat{e} e$ 'take something up' \\
OVER & lóó 'go over' & $l: u u$ 'cross over something' & $l: u u$ 'take something over' \\
DOWN & ghî̀ 'go down' & 'nuw:o 'descend something' & ghîp 'take something down' \\
LEVEL & paa 'go (level)' & $k w o l o$ 'traverse flat area' & dnyênê 'take something along' \\
\hline
\end{tabular}




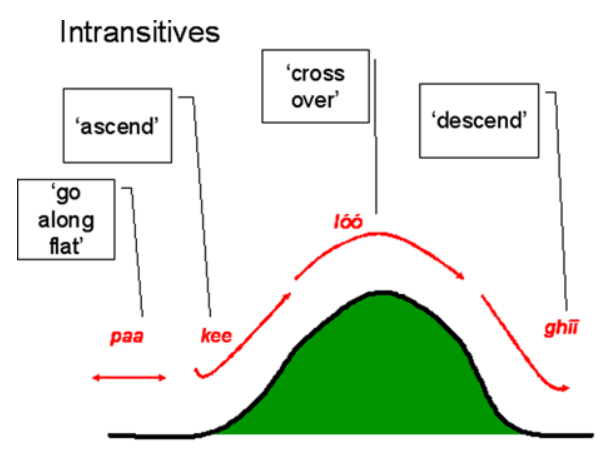

'Landscape Transitives' (object $=$ landform)

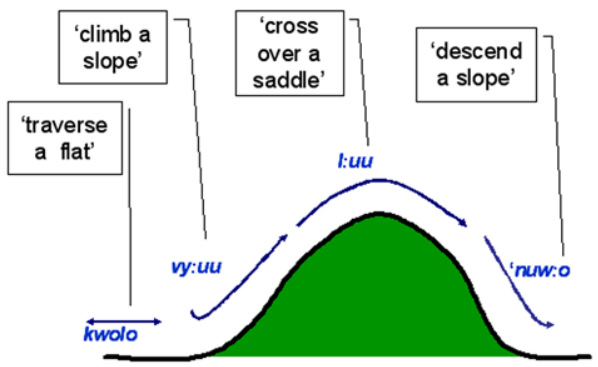

'CARRY Transitives'

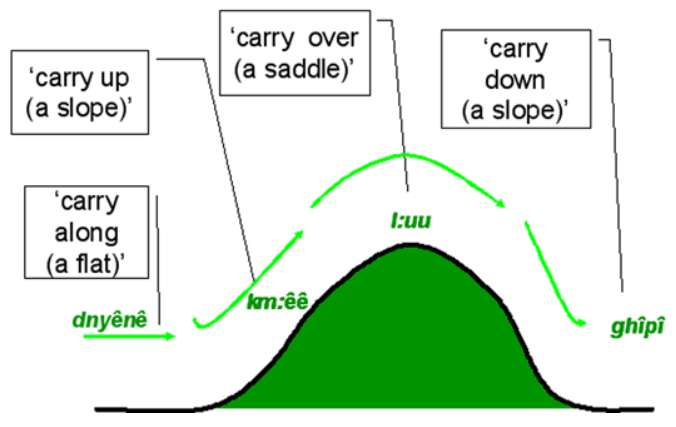

Fig. 18. UP/OVER/DOWN semantic scheme underlying three sets of verbs (1 intransitive set, 2 transitive sets).

Table 11

The UP/DOWN/OVER oppositions applied to watercourses

\begin{tabular}{lll}
\hline Direction & Intransitive & Landscape transitive \\
\hline UP & kee 'go up' & vy:uu 'climb up watercourse' \\
OVER & yima 'cross (over water)' & ngmêe 'cross over water' \\
DOWN & ghî̀ 'go down' & 'nuw: 'follow down water' \\
\hline
\end{tabular}

conceived of as having three distinct segments, as was shown in Fig. 9. In these expressions one 'follows up/down a stream/estuary, etc.'.

We begin to see the importance of the underlying UP/DOWN/ACROSS cultural template. There is also another kind of application, this time primarily of the UP vs. DOWN motif, which label the two fundamental fixed directions in Rossel cosmology, namely East and West. The reason for the conception of East as UP has less to do, I believe, with the sun, than with the prevailing winds: the trade winds blow from the (South) East for most of the year, making canoe travel upwind difficult (by paddling or punting with a pole), but sailing downwind (West) easy. ${ }^{10}$

\footnotetext{
${ }^{10}$ A reviewer queried whether the predominantly East-West axis of island and barrier reefs might also have something to do with it, noting that the trade winds are from the SE rather than due East. In any case, whatever the motivational origin of the coordinates, they are fixed due East-West, and do not of course vary with the wind direction - in that sense they are proper absolute coordinates in the sense explained in Levinson (2003), that is, abstract directions fixed without reference to the body or to landmarks.
} 


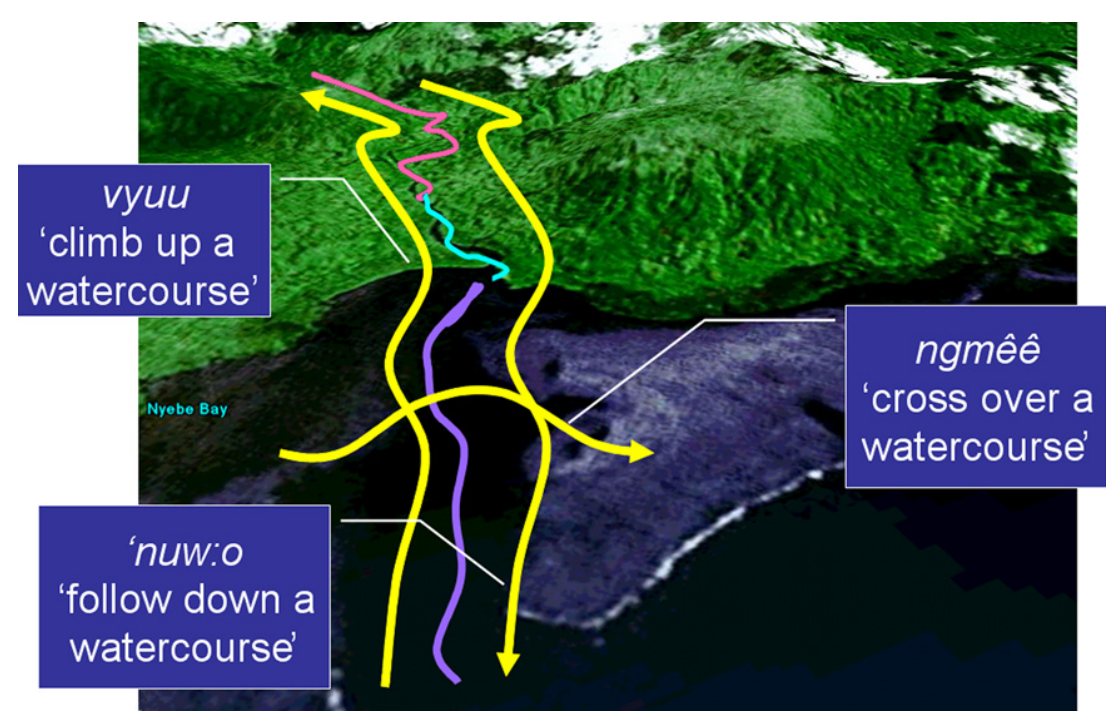

Fig. 19. Application of the UP/OVER/DOWN scheme to water-courses (illustrated with 'landscape transitives'). The three segments of the water course share verbs of 'climb up $\mathrm{X}$ ' and 'follow down $\mathrm{X}$ ' with ascending/ descending elevations, but there is a special verb for 'crossing over (a watercourse)'.

Fig. 20 shows the application of the intransitive and 'carry' transitive verbs (as in Fig. 18) to the macro-geographic scale of the whole island, as tabulated in Table 12.

The landscape transitives can also be used with an absolute directional sense: thus the verb vуии 'ascend a slope' can also mean 'go east', and 'nuw:o, 'descend a slope' can also mean 'go west'. (There is incidentally a general verb, têe $d \hat{\imath}$ 'bring by boat', which is neutral over direction.) This interpretation of the UP/DOWN opposition in terms of an 'absolute' or directionally-fixed frame of reference (see Levinson, 2003, for the theory here) is far reaching. Thus the 'landscape transitives' in Fig. 18 also have absolute interpretations: dê vy:uu can mean 'He went up East', and dê 'nuw:o 'He went down West'.

The ACROSS direction in the system of absolute directions is handled in two ways. First, the directions 'to the mountains' vs. 'to the sea' provide a useful orthogonal when on the North or South of the island. Second, as shown in Fig. 20, all directions away from the island other than Eastwards, can be considered DOWN - thus sailing north or south away from the island can be called 'going down'. The underlying conceptual topography is the same, I suggest, as that of an inclined mountain ridge, as shown in Fig. 21: it is as easy to sail in all directions other than East as it is to descend a ridge in any direction other than up. If this is correct, the underlying concept is built on 'force dynamics': Going up a ridge, and going East are both against the prevailing forces.

It is interesting that there is a close analogy between this kind of an absolute direction system and the kind reported from highland Mayan cultures, where the template is a 'tilted world' (Brown and Levinson, 1993; Levinson, 2003; Brown, this issue). Just as there, there is a three-way ambiguity of the UP/DOWN expressions: UP can mean East, and it can mean a local inclined plane in any direction, and it can mean vertically UP (as with climbing a tree), when the same 'landscape transitives' then apply.

The underlying template in Fig. 21 has direct expression in nominals that name the end points of these trajectories, or trajectories that run over or parallel along the flank, as 


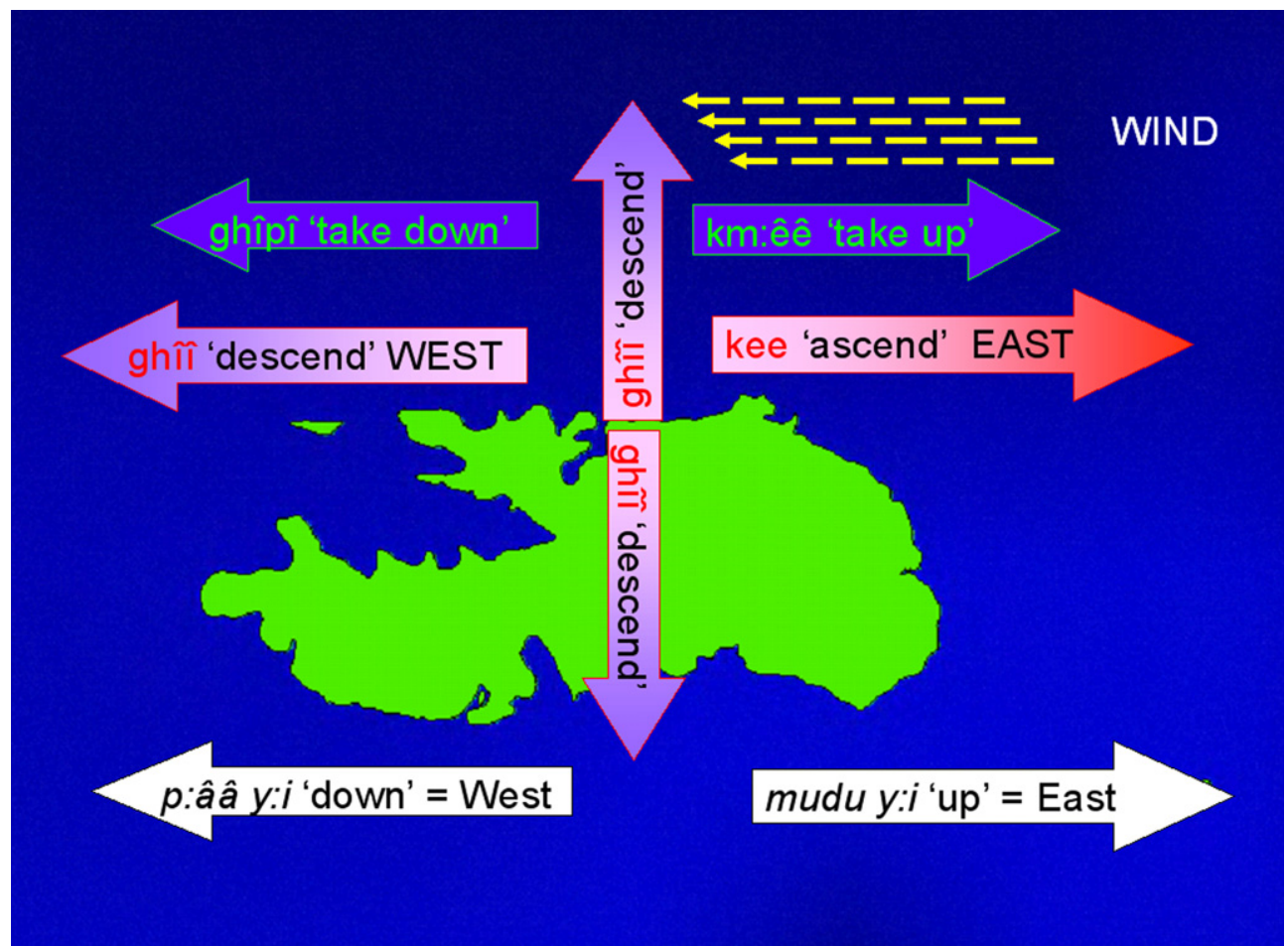

Fig. 20. Application of the UP/DOWN schema to the macroscale of sea journeys. Illustrated here with (a) the intransitive motion verbs (note 'descend' covers motion West, North and South), (b) the 'landscape' transitive verbs. The directions East and West are labelled with adverbs meaning 'up' and 'down' (bottom). The prevailing winds are from the east (top).

Table 12

'Up' and 'Down' oppositions as absolute directions

\begin{tabular}{llll}
\hline & Directions & Intransitives & 'Carry' transitives \\
\hline $\mathrm{UP}=$ EAST & $m u d u$ y: $i$ & kee & $k m: \hat{e} \hat{e} / k n \hat{\imath}$ \\
DOWN =WEST & $p: \hat{a} \hat{a} y: i$ & ghî̀ & ghîp $\hat{\imath}$ \\
\hline
\end{tabular}

shown in Table 13 and Fig. 22. Note too that we now understand that the system of 'top' and 'bottom' ends of each of the three river segments shown in Fig. 9 is in fact just an instantiation of the same schema to rivers.

These nominals play an important role in many of the most frequent place names or place descriptions, as illustrated in Table 14, including the 'tops' and 'bottoms' of named river segments which are place names too.

We now see that this underlying UP/DOWN/OVER model explains a great deal of facts, from verb paradigms, to riverine terminology, to marine directional terminology, to place names. As with other such models that have been reported (cf. Brown and Levinson, 1993), the template is independent of linguistic instantiation - it is a semantic schema that may vary in its surface manifestations (as when the 'landscape transitive' ACROSS verb has a specialized form for rivers), and organize different linguistic sets, 


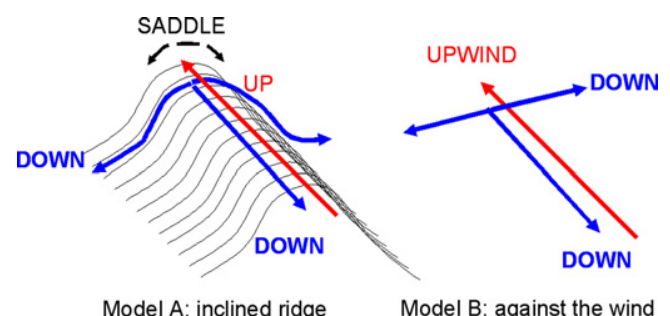

Fig. 21. The underlying cultural template - a 'force dynamics' model. Model A is an inclined ridge (dêpwo), which is clearly applicable to landscape elevations and, with some modifications, to water courses. Model B is applicable to sea-journeys. The generalization is a 'force dynamics' model, in which it is hard to go up in one direction, easier to go down in any other.

Table 13

Nominals tied into the underlying schema, with application to ridges, rivers, paths

\begin{tabular}{llll}
\hline & Ridges, mountains & Water courses & Paths \\
\hline TOP & mbêmê, $k \hat{a} \hat{a}$ & $n k o o$ & $n k o o / n y e d \hat{e}$ \\
BOTTOM & vyuwo, $k n: \hat{a} a$ & $k n: \hat{a} \hat{a}$ & kn:ââ \\
SADDLE & chóó & - & nyedê \\
FLANK & paa & paa & \\
\hline
\end{tabular}

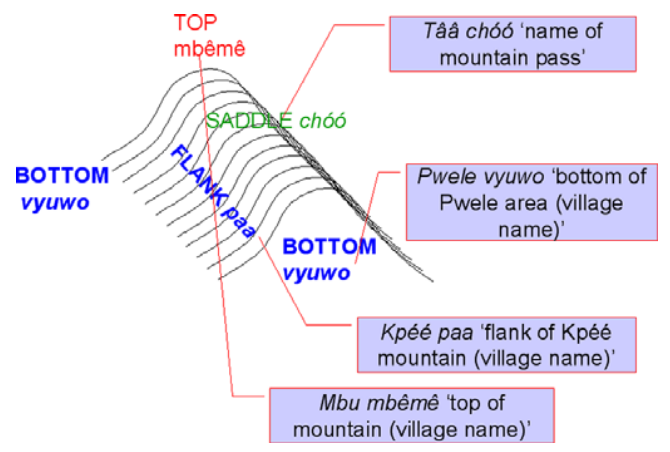

Fig. 22. The static version of the cultural template, as revealed in toponyms The inclined ridge model is also instantiated in nominals labelling the TOP, BOTTOM, SADDLE and FLANK. These nominals play an important role in the formation of toponyms, as illustrated.

Table 14

Place names built on the nominals in Table 13

\begin{tabular}{llll}
\hline & Village names & Area names & Riverine/lagoon areas \\
\hline TOP & Mbu mbêmê & Pyidi nyedê & Pene nkoo \\
BOTTOM & Pwele vyuwo & Mywede vyuwo & Pene kn:ââ \\
SADDLE & Mbwâpu chóó & Mwéni chóó & - \\
FLANK & Kpéé paa & Dpîmê paa & Mbwaa paa \\
\hline
\end{tabular}

nominal and verbal, in paradigmatic oppositions. For this reason, such cultural templates are sometimes hard to recognized, and may be much more frequent than have been reported. Although this notion of template is semantic in character, it does not fit the 
existing pigeon holes of semantic theory - it is a generalization that is not directly recoverable from lexical entries, but is not restricted to a single domain or semantic field either. There is reason to believe that such templates may in fact play an important role in structuring both native conception and the lexicon.

\section{Conclusions}

The patterns of landscape/seascape terminology and the associated proper names on Rossel Island serve to establish a number of fundamental facts about the comparative linguistics of the geophysical domain:

1. The facts above show that concepts of the kind 'mountain', 'river', 'sea', which might be plausible candidates for universals in the landscape domain, will not be found in all languages, even in the appropriate ecologies. We have seen for example that $m b u$ denotes conical peaks of any size, that 'river' has no counterpart in the Rossel scheme of things, which instead recognizes both larger and smaller entities, and that Rossel lacks a general 'sea' or 'ocean' term (ntii 'salt water' comes closest), instead making much finergrained distinctions based on depth, type of bottom, distance from land, and so forth. Although the failure to find universal concepts in this domain may not in retrospect be surprising (Saussure had already prefigured it), in an age of universal geographical mapping systems this lack of a universal ontological grid is important to take on board (as Mark and Turk, 2003a,b, 2004, have emphasized).

2. The facts also show that perceptual salience is not the most important driving force behind human categorization of the environment. The idea that there might be strong universals in this domain clearly derives from the assumption that, although the planet has a continuous geophysical surface, humans would, given their organs of perception and cognition, find 'natural' discontinuities or at least highly salient prototypes in that surface. In fact, of the three plausible motivations behind human categorization in this area (perceptual salience, human affordance, and cultural models), the Rossel facts suggest the predominance of the latter two factors - only the term $m b u$ clearly has a primarily perceptual motivation. Of the other two factors, the cultural factors are probably predominant. This is in part because, as we have seen, such factors as administrative units/regions of ownership, cultural alterations of the landscape, and religious beliefs play an important role in establishing discontinuities and designated places. It is in part because cultural templates - implicit but insistent frameworks of thought characteristic of a community - play an important role in structuring linguistic distinctions as shown in the prior section. But it is also because human affordance is ultimately a cultural matter itself: the mode of subsistence, the manner of transport, the available technology are all cultural matters. If the inhabitants of Rossel did not use canoes and did not have to gather protein in the wild, the distinctions between the three segments of a river would make little sense.

3. The Rossel facts also show that, although the ontological entities presumed in landscape terms may be quite unlike English ones, the relationship between the landscape terms and toponyms can be very close indeed, even closer than in English. For Rossel Island, if there is a landscape or seascape term, there is in the great majority of cases a corresponding set of toponyms that pick out specific instances of that category (the few category terms that lack corresponding toponyms may reflect inadequate ethnography 
on my part). This in part reflects the density of toponyms on land and sea, which may well be typical for small island communities in the Pacific. The generalization this suggests, namely that landscape terms always provide the ontological basis for toponyms we know however to be false (see Burenhult, this issue).

Although these findings are interesting, there remain many linguistic properties of the geophysical domain that have yet to be properly explored. Questions include, for example, the role of prototype models, of a kind appropriate for English mountain (with a shape + magnitude prototype) and Rossel $m b u$ (with shape alone), for English river (with magnitude distinctions from stream, etc.) but not for Rossel mbwaa ('fresh water course of any size'). They include also the role of partonymy, which in principle might be thought to govern this domain - after all, landscape features are part of larger features, which are in turn part of the overall geophysical surface. The Rossel district terms described above, clearly are partonymic - it makes sense to say 'Is Keedêdê wee part of Wópuchêdê wee'? But it does not make sense to ask the equivalent of 'Is Everest part of the Himalayas?', because $m b u$ elevations do not seem to be generally thought of as parts of larger ranges. The fact that the mountain $M g \hat{\imath}$ occurs in the string of peaks labelled ' $M g \hat{\imath}$ and his nephews' (see Fig. 16 above) does not demonstrate the contrary - here the relation is set-theoretic not mereological (partonymic). Understanding this fine-grained semantic nuance would be essential to explaining the entailments that follow from statements of the kind "I am on Everest" (entailing "I am not on K2" but "I am in the Himalayas" and "I am on a mountain"), but not, it seems, from its Rossel counterpart.

\section{References}

Armstrong, W.E., 1928. Rossel Island: An Ethnological Study. Cambridge University Press, Cambridge.

Basso, K.H., 1984. Western Apache place name hierarchies. In: Tooker, E. (Ed.), Naming Systems. Proceedings of the American Ethnological Society, vol. 4, pp. 78-94.

Bennardo, G., 2005. Radiality in Tongan Production About Social Relations. Paper presented to the American Anthropological Association, Washington, DC, December 4, 2005.

Berlin, B., 1992. Ethnobiological Classification. Princeton University Press, Princeton.

Brown, P., Levinson, S., 1993. 'Uphill' and 'downhill' in Tzeltal. Journal of Linguistic Anthropology 3 (1), $46-74$.

Burenhult, N., 2005. Landscape terms and toponyms in Jahai: a field report. Working Papers 51. Department of Linguistics, Lund, pp. 17-29.

Dunn, M., Terrill, A., Reesink, G., Foley, R., Levinson, S.C., 2005. Structural phylogenetics and the reconstruction of ancient language history. Science 309, 2072-2075.

Feinberg, R., 2005. Structures of Geographic and Cosmological Space: a Polynesian Case Study. Paper presented to the American Anthropological Association, Washington, DC, December 4, 2005.

Goodenough, W.H., 1951. Property, Kin and Community on Truk. Yale University Press, New Haven.

Horton, R., 1982. Tradition and modernity revisited. In: Hollis, M., Lukes, S. (Eds.), Rationality and Relativism. Blackwell, Oxford, pp. 201-260.

Hunn, E., 1996. Columbia Plateau Indian place names: What can they teach Us? Journal of Linguistic Anthropology 6, 3-26.

Kari, J., 1989. Some principles of Alaskan Athabaskan toponymic knowledge. In: Kay, M.R., Hoenigswald, H.M. (Eds.), General and Amerindian Ethnolinguistics: In Remembrance of Stanley Newman. Mouton de Gruyter, New York, pp. 129-149.

Levinson, S.C., 2002. Landscape terms and place names in Yélî Dnye, the language of Rossel Island, PNG'. In: Kita, S. (Ed.), 2002 Supplement (Version 2) for the 'Manual' for the Field Season 2001. Max Planck Institute for Psycholinguistics, Nijmegen, pp. 7-12.

Levinson, S.C., 2003. Space in Language and Cognition: Explorations in Cognitive Diversity. Cambridge University Press, Cambridge. 
Levinson, S.C., 2006. Matrilineal clans and kin terms on Rossel Island. Anthropological Linguistics 48 (1), 1-43.

Majid, A., Enfield, N.J., van Staden, M. (Eds.), 2006. Cross-Linguistic Categorization of the Body. Language Sciences 28.

Mark, D.M., Turk, A.G., 2003a. Ethnophysiography. Paper presented at: Workshop on Spatial and Geographic Ontologies, September 23, 2003 (prior to COSIT03).

Mark, D.M., Turk, A.G., 2003b. Landscape categories in Yindjibarndi: ontology, environment, and language. In: Kuhn, W., Worboys, M., Timpf, S. (Eds.), Spatial Information Theory: Foundations of Geographic Information Science, . In: Lecture Notes in Computer Science, vol. 2825. Springer-Verlag, Berlin, pp. 28-45.

Mark, D.M., Turk, A.G., 2004. Ethnophysiography and the ontology of landscape. In: Proceedings of GIScience, pp. $152-155$.

Smith, B., Mark, D.M., 2001. Geographical categories: an ontological investigation. International Journal of Geographical Information Science 15 (7), 591-612.

Smith, B., Mark, D.M., 2003. Do mountains exist? Towards an ontology of landforms. Environment and Planning B: Planning and Design 30 (3), 411-427. 